\title{
Sulphur compounds, methane, and phytoplankton: interactions along a north-south transit in the western Pacific Ocean
}

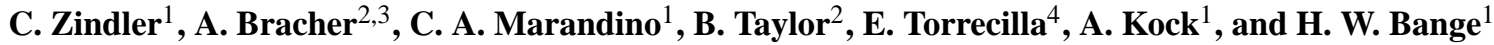 \\ ${ }^{1}$ Forschungsbereich Marine Biogeochemie, GEOMAR Helmholtz-Zentrum für Ozeanforschung Kiel, \\ Düsternbrooker Weg 20, 24105 Kiel, Germany \\ ${ }^{2}$ Alfred-Wegener-Institute of Polar and Marine Research, Bremerhaven, Germany \\ ${ }^{3}$ Institute of Environmental Physics, University of Bremen, Germany \\ ${ }^{4}$ Institute of Marine Sciences, Mediterranean Marine and Environmental Research Centre (ICM, CSIC), Barcelona, Spain
}

Correspondence to: C. Zindler (czindler@geomar.de)

Received: 16 October 2012 - Published in Biogeosciences Discuss.: 29 October 2012

Revised: 18 April 2013 - Accepted: 19 April 2013 - Published: 16 May 2013

\begin{abstract}
Here we present results of the first comprehensive study of sulphur compounds and methane in the oligotrophic tropical western Pacific Ocean. The concentrations of dimethylsuphide (DMS), dimethylsulphoniopropionate (DMSP), dimethylsulphoxide (DMSO), and methane $\left(\mathrm{CH}_{4}\right)$, as well as various phytoplankton marker pigments in the surface ocean were measured along a north-south transit from Japan to Australia in October 2009. DMS $\left(0.9 \mathrm{nmol} \mathrm{L}^{-1}\right)$, dissolved DMSP $\left(\mathrm{DMSP}_{\mathrm{d}}, 1.6 \mathrm{nmol} \mathrm{L}^{-1}\right)$ and particulate DMSP (DMSP, 2 nmol L$\left.^{-1}\right)$ concentrations were generally low, while dissolved DMSO $\left(\mathrm{DMSO}_{\mathrm{d}}, 4.4 \mathrm{nmol} \mathrm{L}^{-1}\right)$ and particulate DMSO $\left(\mathrm{DMSO}_{\mathrm{p}}, 11.5 \mathrm{nmol} \mathrm{L}^{-1}\right)$ concentrations were comparably enhanced. Positive correlations were found between DMSO and DMSP as well as DMSP and DMSO with chlorophyll $a$, which suggests a similar source for both compounds. Similar phytoplankton groups were identified as being important for the DMSO and DMSP pool, thus, the same algae taxa might produce both DMSP and DMSO. In contrast, phytoplankton seemed to play only a minor role for the DMS distribution in the western Pacific Ocean. The observed $\mathrm{DMSP}_{\mathrm{p}}: \mathrm{DMSO}_{\mathrm{p}}$ ratios were very low and seem to be characteristic of oligotrophic tropical waters represent-

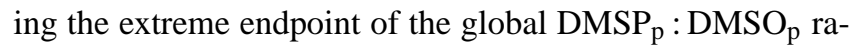
tio vs SST relationship. It is most likely that nutrient limitation and oxidative stress in the tropical western Pacific Ocean triggered enhanced DMSO production leading to an accumulation of DMSO in the sea surface. Positive correlations between $\mathrm{DMSP}_{\mathrm{d}}$ and $\mathrm{CH}_{4}$, as well as between DMSO (particulate and total) and $\mathrm{CH}_{4}$, were found along the transit.
\end{abstract}

We conclude that DMSP and DMSO and/or their degradation products might serve as potential substrates for $\mathrm{CH}_{4}$ production in the oxic surface layer of the western Pacific Ocean.

\section{Introduction}

Oceanic dimethylsulphide (DMS) is the most important source of biogenic sulphur to the atmosphere and, thus, the oceanic DMS flux constitutes a significant component of the global sulphur cycle, see e.g. Vogt and Liss (2009). The oceanic distributions of DMS and its major precursor dimethylsulphoniopropionate (DMSP) result from a complex interplay of biological and non-biological pathways, such as formation by phytoplankton and microbial cleavage of DMSP to DMS on the one hand, and microbial consumption as well as photochemical oxidation of DMS and its loss to the atmosphere on the other hand (Simó, 2004; Stefels et al., 2007; Vogt and Liss, 2009; Schäfer et al., 2010). Although dimethylsulphoxide (DMSO) is recognized as an important reservoir of sulphur in the ocean, its production and consumption pathways are poorly understood. The principal production mechanisms for DMSO are the photochemical and bacterial oxidation of DMS, as well as direct synthesis in marine algae cells (Lee and De Mora, 1999; Lee et al., 1999a). Bacterial consumption, reduction to DMS, further oxidation to dimethylsulphone $\left(\mathrm{DMSO}_{2}\right)$, and export to deep waters via sinking particles are possible sinks for DMSO in the euphotic zone (Hatton et al., 2005). It is well known that DMS, DMSP 
and DMSO play important roles in the oceanic nutrient cycle. They are ubiquitous in the ocean and are responsible for the transfer and cycling of sulphur and carbon between different trophic levels in plankton (Kiene et al., 2000; Simó, 2004; Simó et al., 2002; Yoch, 2002). DMSP, for example, can completely satisfy the sulphur demand for bacterioplankton and can deliver $48 \%$ of the sulphur requirement for microzooplankton (Kiene and Linn, 2000; Simó, 2004). Additionally, DMSP can supply between 8 and $15 \%$ of carbon for bacteria and can serve as an energy source, which makes it the most important single substrate for marine bacterioplankton (Kiene et al., 2000; Simó et al., 2002). DMSO seems to be an important substrate for specialized bacteria that use DMSO as carbon or electron source (Lee et al., 1999a; Simó et al., 2000).

Methane $\left(\mathrm{CH}_{4}\right)$ is an atmospheric trace gas that contributes significantly to the greenhouse effect and chemistry of the Earth's atmosphere (IPCC, 2007). $\mathrm{CH}_{4}$ is mainly produced by methanogenesis as part of the microbial decomposition of organic matter (Cicerone and Oremland, 1988; Ferry, 2010). Despite the fact that methanogenesis requires strictly anaerobic conditions (see e.g. Ferry, 2010), $\mathrm{CH}_{4}$ concentrations above the equilibrium concentration with the atmosphere are usually found in the ventilated (i.e. oxic) open ocean surface layer (see e.g. Reeburgh, 2007). This indicates that the open ocean is indeed a source of $\mathrm{CH}_{4}$ to the atmosphere. Several explanations for this obvious "oceanic $\mathrm{CH}_{4}$ paradox" have been suggested. For example, methanogens might live in anoxic micro-niches such as found in sinking organic particles and inside of zooplankton guts (de Angelis and Lee, 1994; Karl and Tilbrook, 1994). Only recently Karl et al. (2008) suggested an aerobic $\mathrm{CH}_{4}$ production pathway by Trichodesmium, which can use methylphosphonate as an alternative phosphate source. The degradation products of DMSP (i.e. methanethiol, methylmercaptopropionate and DMS) have been suggested as important methylated precursors for marine microbial $\mathrm{CH}_{4}$ production under anoxic conditions (Finster et al., 1992; Tallant and Krzycki, 1997) as well as oxic conditions (Damm et al., 2010, 2008). Methanogenic archaea have been identified to have the ability to metabolize DMSP and its degradation products by producing $\mathrm{CH}_{4}$ (Kiene et al., 1986; Oremland et al., 1989; van der Maarel and Hansen, 1997). Accumulation of $\mathrm{CH}_{4}$, dependent on DMSP consumption in the surface ocean, has been observed under oligotrophic conditions as well as in a phytoplankton bloom (Damm et al., 2010).

This study presents measurements of the surface ocean distributions of DMS, DMSP, DMSO, $\mathrm{CH}_{4}$ and phytoplankton pigments in the western Pacific Ocean, an area that is considerably undersampled for all of the listed compounds. By using statistical methods we investigated (i) the interactions and links between the different sulphur compounds and how these might control their distributions, (ii) the role of phytoplankton community composition in determining the surface distributions of the sulphur compounds and (iii) the role of sulphur compounds as potential precursors for $\mathrm{CH}_{4}$ in the surface ocean. All data were retrieved during a northsouth transit cruise in October 2009 (Krüger and Quack, 2012) as part of the TransBrom project.

\section{Methods}

Water samples were collected aboard the R/V Sonne from 9 to 24 October 2009 during a transit cruise from Tomakomai (Japan) to Townsville (Australia) in order to analyse the sea surface concentrations of DMS, DMSP, DMSO, $\mathrm{CH}_{4}$ and phytoplankton composition (Fig. 1). Samples were collected every three or twelve hours from approximately $5 \mathrm{~m}$ depth using the underway pump system installed in the hydrographic shaft. One $250 \mathrm{~mL}$ sample was collected for sulphur compound analysis, three $25 \mathrm{~mL}$ samples were collected for $\mathrm{CH}_{4}$ analysis and one 5-13 L sample was collected for determination of phytoplankton pigments.

\subsection{Analysis of sulphur compounds and $\mathrm{CH}_{4}$}

Out of the $250 \mathrm{~mL}$ sulphur sample, three replicate subsamples $(10 \mathrm{~mL})$ were analysed for DMS, dissolved DMSP $\left(\mathrm{DMSP}_{\mathrm{d}}\right)$ and DMSO $\left(\mathrm{DMSO}_{\mathrm{d}}\right)$. The total and, thus, the particulate fraction of DMSP (DMSP, $\mathrm{DMSP}_{\mathrm{p}}$ ) and DMSO $\left(\mathrm{DMSO}_{\mathrm{t}}, \mathrm{DMSO}_{\mathrm{p}}\right)$ were analysed in additional three replicate sub-samples $(10 \mathrm{~mL})$ taken from the $250 \mathrm{~mL}$ sample. Samples were measured immediately after collection, with the exception of DMSO. DMSO samples were stored in the dark and analysed later in the GEOMAR (Helmholtz Centre for Ocean Research Kiel) laboratory directly after the cruise. It has been shown that storage of DMSO in hydrolysed samples with gas tight closure does not alter the DMSO concentration (Simó et al., 1998). Samples for the analysis of DMS and the dissolved fraction of DMSP and DMSO were gently filtered by using a syringe as described in Zindler et al. (2012). DMS, DMSP $P_{d}$ and $D_{M S P}$ samples were analysed by purge and trap coupled to a gas chromatograph-flame photometric detector (GC-FPD) on-board immediately after sampling, as described in Zindler et al. (2012). Two minor modifications were made: (i) replacement of the previously used Tenax with trapping in liquid nitrogen, (ii) injection onto the GC by immersion in hot water. DMS was analysed first in the samples. Afterwards $\mathrm{DMSP}_{\mathrm{d}}$ was measured out of the same samples by converting DMSP into DMS using sodium hydroxide $(\mathrm{NaOH})$. DMSP $_{\mathrm{t}}$ was analysed from unfiltered alkaline sub-samples. $\mathrm{DMSP}_{\mathrm{p}}$ was calculated by subtracting DMS and $\mathrm{DMSP}_{\mathrm{d}}$ from the $\mathrm{DMSP}_{\mathrm{t}}$ value. After the DMSP analysis, the alkaline samples were stored for DMSO measurements back in the lab at GEOMAR. $\mathrm{DMSO}_{\mathrm{d}}$ and $\mathrm{DMSO}_{\mathrm{t}}$ were analysed from the same samples used for analysing $\mathrm{DMSP}_{\mathrm{d}}$ and $\mathrm{DMSP}_{\mathrm{t}}$, respectively. DMSO was converted into DMS by adding cobalt dosed sodium borohydride $\left(\mathrm{NaBH}_{4}\right)$ and analysed immediately with the 


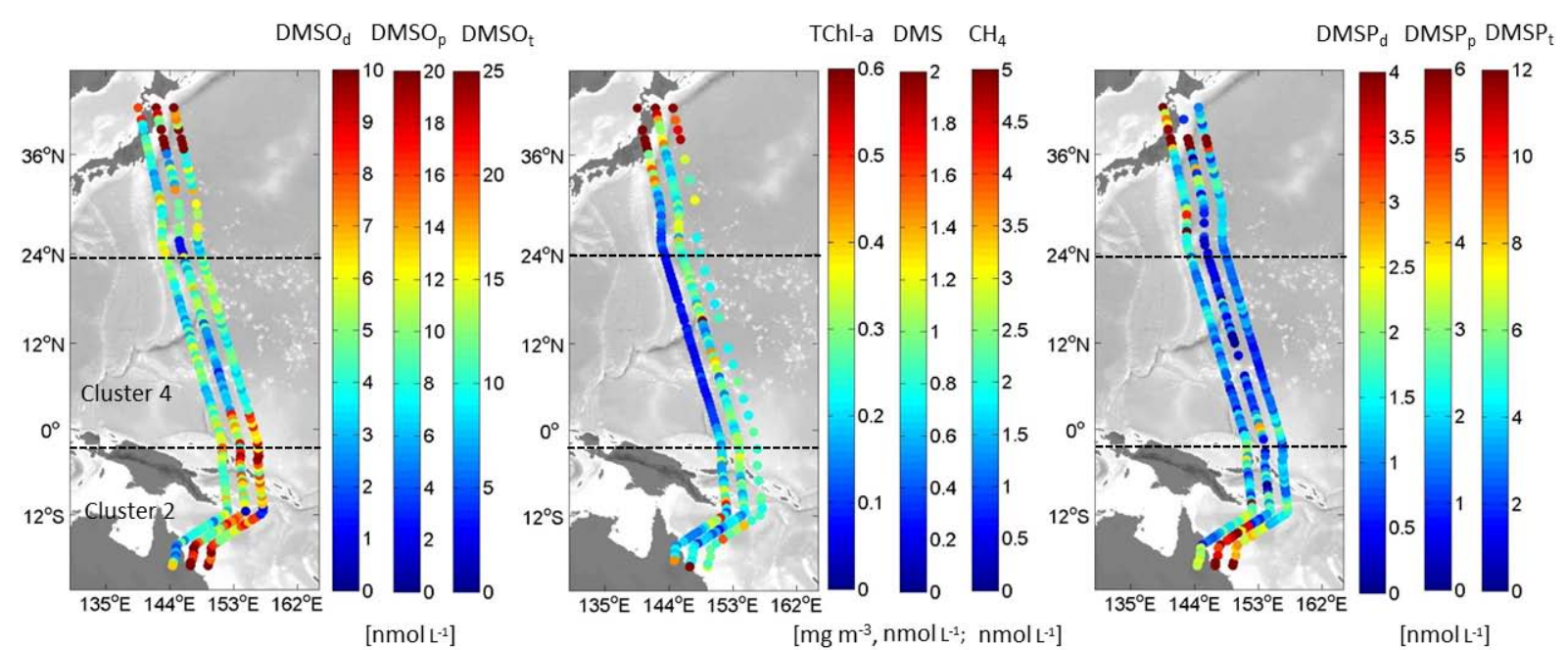

Fig. 1. Distribution of (a) DMSO (nmol L $\left.{ }^{-1}\right)$, (b) total Chl $a\left(\mathrm{mg} \mathrm{m}^{-3}\right)$ (HPLC in situ measurements), DMS, and methane (nmol $\left.\mathrm{L}^{-1}\right)$, and (c) DMSP (nmol L ${ }^{-1}$ ) along the cruise track. The middle line in each panel shows the exact position of the cruise track. The dashed lines show the approximate location of clusters 2 and 4 . The order of the colour bars corresponds to the order of the individual coloured cruise tracks in the figure panels.

same technique as mentioned above. The final $\mathrm{DMSO}_{\mathrm{p}}$ values were calculated by subtracting $\mathrm{DMSO}_{\mathrm{d}}$ from the total DMSO concentration. The mean errors given as standard deviations of the triplicate measurements, calculated according to David (1951) were $\pm 0.2 \mathrm{nmol} \mathrm{L}^{-1}( \pm 20 \%)$ for DMS, $\pm 0.4 \mathrm{nmol} \mathrm{L}^{-1}( \pm 23 \%)$ for $\mathrm{DMSP}_{\mathrm{d}}$, and $\pm 0.5 \mathrm{nmol} \mathrm{L}^{-1}$ $( \pm 20 \%)$ for particulate $\mathrm{DMSP}_{\mathrm{p}}$. For $\mathrm{DMSO}_{\mathrm{p}}$ and $\mathrm{DMSO}_{\mathrm{d}}$ a mean analytical error of $\pm 2.3 \mathrm{nmol} \mathrm{L}^{-1}( \pm 15 \%)$ and $\pm 0.5 \mathrm{nmol} \mathrm{L}^{-1}( \pm 12 \%)$ was determined, respectively. Calibrations using liquid standards were conducted every second day during the cruise and during the analysis in the lab. The precision and accuracy of the system was tested in the lab prior the cruise as described in Zindler et al. (2012). The entire analytical system was tested for blanks with carrier gas only and together with pure $18 \mathrm{M} \Omega$ Milli-Q water (used for cleaning and standard preparation) as well as Milli-Q water enriched with sodium hydroxide in order to exclude contamination with environmental DMSO.

Concentrations of dissolved $\mathrm{CH}_{4}$ were measured with a static equilibration method as described in detail in Bange et al. (2010). The samples were poisoned with $\mathrm{HgCl}_{2}$ (aq) and analysed immediately after the cruise in the GEOMAR laboratory. The mean analytical error of dissolved $\mathrm{CH}_{4}$ measurements was $\pm 17 \%$. $\mathrm{CH}_{4}$ saturations (Sat in \%) were roughly estimated as $\mathrm{Sat}=100\left[\mathrm{CH}_{4}\right] /\left[\mathrm{CH}_{4}\right]_{\text {eq }}$, where $\left[\mathrm{CH}_{4}\right]_{\text {eq }}$ is the equilibrium concentration (see Wiesenburg and Guinasso Jr., 1979) calculated with the in situ temperature and salinity and a mean atmospheric $\mathrm{CH}_{4}$ dry mole fraction of $1.80 \mathrm{ppm}$, which was considered to be a representative mean for the western Pacific Ocean during the time of the transit (Terao et al., 2011).

\subsection{Phytoplankton analysis}

\subsubsection{Phytoplankton pigments and group composition}

Water samples for pigment and absorption analysis were filtered on GF/F (glass fibre/filters) filters, shock-frozen in liquid nitrogen, stored at $-80^{\circ} \mathrm{C}$ and analysed in the AWI (Alfred Wegener Institute) laboratory immediately after the cruise. The analysis of phytoplankton pigments was performed with high performance liquid chromatography (HPLC) according to Taylor et al. (2011). Particulate and phytoplankton absorption was determined with a dual-beam UV/VIS (ultraviolet/visible) spectrophotometer (Cary 4000, Varian Inc.) equipped with a $150 \mathrm{~mm}$ integrating sphere (external DRA-900, Varian, Inc. and Labsphere Inc., made by Spectralon ${ }^{\mathrm{TM}}$ ) using a quantitative filter pad technique as described in a modified version in Taylor et al. (2011) (for more details see also Rottgers and Gehnke, 2012).

Table 2 in Taylor et al. (2011) summarizes the pigments analysed in this study and provides the information about which pigments have been allocated as marker pigments for the different phytoplankton groups. According to a procedure proposed by Vidussi et al. (2001), which was modified by Uitz et al. (2006) and most recently by Hirata et al. (2011), we estimated the contributions of three phytoplankton size classes (i.e. micro-, nano- and picophytoplankton representing the size classes of $20-200 \mu \mathrm{m}, 2-20 \mu \mathrm{m}$ and $<2 \mu \mathrm{m}$, respectively) and seven phytoplankton groups based on the measured concentrations of seven diagnostic pigments (DP) to the biomass. The DP, the calculation procedure of the weighted relationships of these marker pigments and the determination of their biomasses are described in the Supplement. 


\subsubsection{Identifying phytoplankton assemblages with hierarchical cluster analysis}

In order to identify clusters of phytoplankton community composition, an unsupervised hierarchical cluster analysis (HCA) according to Torrecilla et al. (2011) was applied. The HCA grouped the individual stations into different clusters according to their phytoplankton pigment compositions. The results were evaluated with an additional clustering based on hyperspectral phytoplankton absorption coefficients (described in detail in the Supplement).

\subsection{Statistical analysis}

Linear regression analysis performed with the statistical computing software by RStudio $^{\mathrm{TM}}$ (R Development Core Team, 2010; http://www.rstudio.org/) was used to identify significant correlations between sulphur compounds as well as between sulphur compounds and $\mathrm{CH}_{4}$. Prior to the regression analysis, data were tested for Gaussian distribution and $\log$-transformed if necessary. The $F$ statistic, the $p$ value and the $R^{2}$ were calculated.

Multiple linear regression models (MLRM) computed with RStudio ${ }^{T M}$ were used to identify how the sulphur compounds might influence each other and which phytoplankton pigments might influence the sulphur compounds (for more details about the analytical procedure see the Supplement). The MLRM were performed for the entire north-south transit and again for the two main sub-regions referred as cluster 2 and cluster 4, which were demarcated according to the phytoplankton composition (Fig. 1, Sect. 3.1). No statistical analysis could be performed for cluster 1 and cluster 3 due to the lack of a sufficient amount of data in these clusters.

\section{Results and discussion}

\subsection{Phytoplankton community structure in the western Pacific Ocean}

In total, 106 surface stations along the north-south transit were measured. Phytoplankton biomass given as total chlorophyll $a$ (TChl $a$ concentration in $\mathrm{mg} \mathrm{m}^{-3}$ ) was very low $\left(0.05-0.25 \mathrm{mg} \mathrm{m}^{-3}\right)$, except for north of $36^{\circ} \mathrm{N}$ (TChl $a>1 \mathrm{mg} \mathrm{m}^{-3}$ ) where colder waters $\left(16-20^{\circ} \mathrm{C}\right)$ of the Oyashio Current were observed, in the vicinity of islands (which were passed at $4,8,10$ and $12^{\circ} \mathrm{S}$ ) and in the region of the Great Barrier Reef (Fig. 1b). Measured concentrations of marker pigments (e.g. fucoxanthin, see the Supplement for full description) and chlorophyll $a$ (Chl $a$ ) along the transit were used to calculate the biomass of the major phytoplankton groups (Fig. 2). The phytoplankton biomass was generally dominated by picoplankton (sum of biomass of prochlorophytes and other cyanobacteria), with at least $50 \%$ contribution by the group of prochlorophytes, except in the Oyashio Current. At the stations with elevated TChl $a$ val-
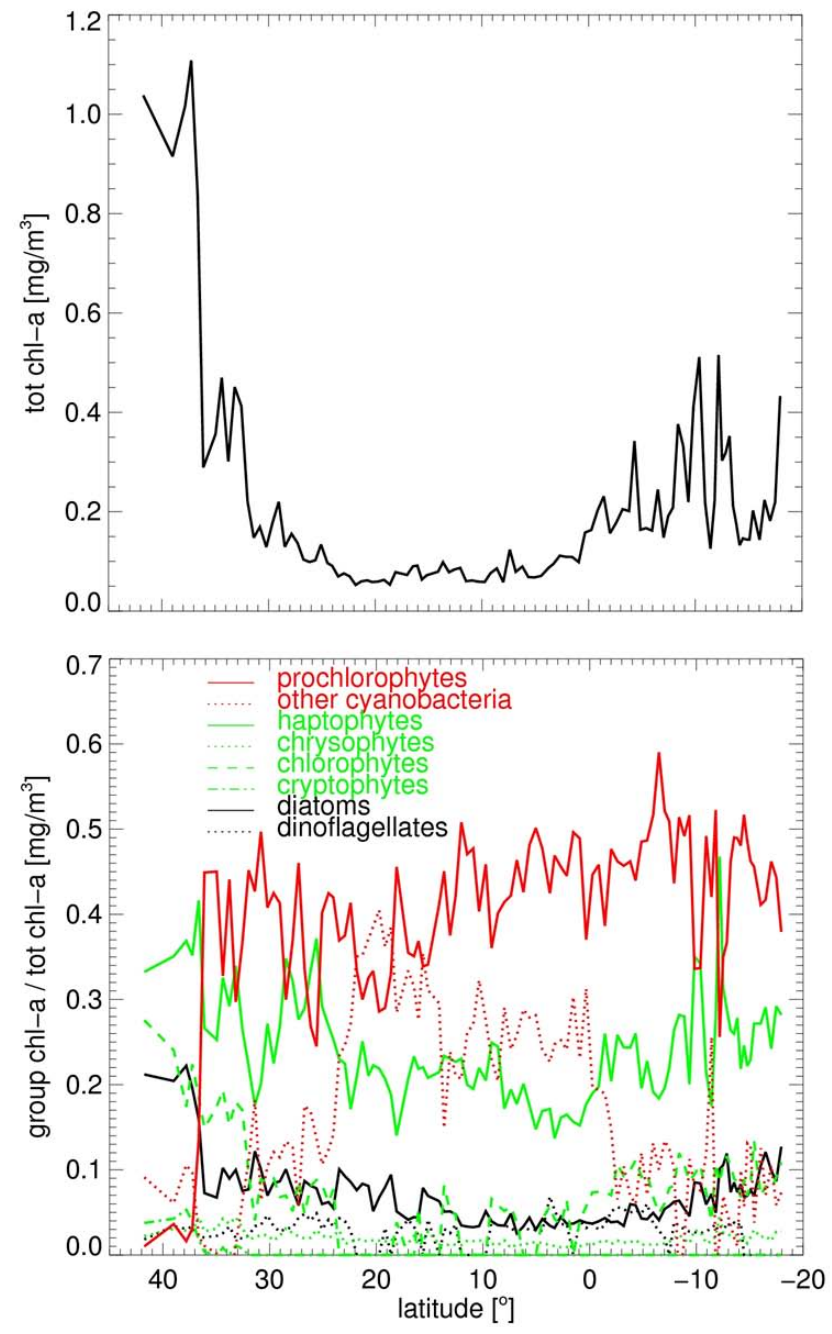

Fig. 2. Total Chl $a$ concentration of main phytoplankton groups $\left(\mathrm{mg} \mathrm{m}^{-3}\right)$ as derived from major pigment composition (upper panel); ratio of phytoplankton groups divided by the TChl $a$ concentration in correspondence to the latitude sampled (lower panel).

ues, haptophytes contributed significantly to the phytoplankton biomass. Diatoms and chlorophytes only made a significant contribution (between 20 and 30\%) to the biomass in the Oyashio Current.

Four phytoplankton-based clusters were identified from the HCA analysis of both the normalized pigment concentrations (Fig. 3) and the hyperspectral phytoplankton absorption coefficients. The resulting cluster trees are presented in the Supplement (Figs. 1, 2, respectively). A high cophenetic index was obtained (i.e. 0.712, see more details in the Supplement) indicating a good agreement between the cluster trees obtained from the pigment and the absorption data set. The partition provided by the absorption data was quite similar to the partition obtained based on the pigment information. For the 106 stations, the ones belonging to the clusters 1, 2 and 4 (and identified in yellow, green and red, respectively) were 


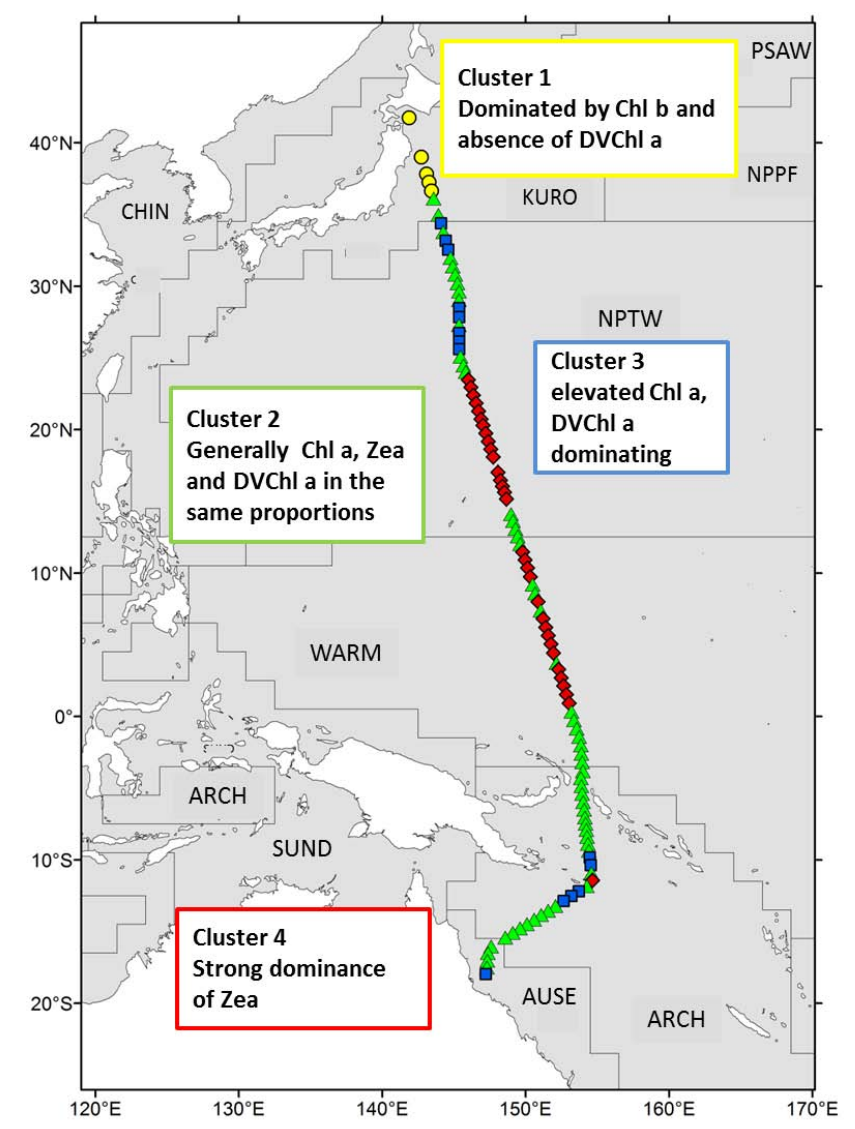

Fig. 3. Distribution of clusters among pigment stations with the Longhurst provinces shown underneath. Yellow indicates cluster 1 (circles), green is cluster 2 (triangles), blue is cluster 3 (squares), and red is cluster 4 (diamonds).

mainly clustered separately but with some salient exceptions as seen for instance for stations: 27, 41, 44-48, 52, 53, 62 and 100 . On the contrary, stations belonging to the cluster 3 (in blue) were not grouped separately and therefore assigned to other clusters.

The stations located in the Oyashio Current (north of $36^{\circ} \mathrm{N}$ ) belong to cluster 1 , which is characterized by high phytoplankton biomass (TChl $a \sim 1 \mathrm{mg} \mathrm{m}^{-3}$ ) and a dominance of eukaryotic algae (mainly chlorophytes and haptophytes, and a smaller contribution from diatoms) and an absence of prochlorophytes. The majority of the stations belong to cluster 2 with low TChl $a\left(0.05-0.3 \mathrm{mg} \mathrm{m}^{-3}\right)$. Cyanobacteria are dominant in cluster 2 , with prochlorophytes contributing more than other cyanobacteria. Cluster 2 stations are mainly found between 36 and $25^{\circ} \mathrm{N}$ (associated with the Kuroshio Current waters) as well as south of the equator (Fig. 3). Cluster 3 stations were found between 36 and $25^{\circ} \mathrm{N}$ (the Kuroshio Current) and south of $10^{\circ} \mathrm{S}$. They are mingled with cluster 2 stations. At cluster 3 stations waters are elevated in TChl $a\left(0.4-0.6 \mathrm{mg} \mathrm{m}^{-3}\right)$ and cyanobacteria, mainly prochlorophytes, are dominant. Haptophytes were identified as the second largest group. Cluster 4 stations are mainly found in waters between $25^{\circ} \mathrm{N}$ and the equator and are characterized by a very low biomass (TChl $a<0.15 \mathrm{mg} \mathrm{m}^{-3}$ ). Cyanobacteria are dominant in cluster 4 almost exclusively with prochlorophytes and other cyanobacteria contributing equally. The spatial distributions of the cluster 1 reflect the biogeographic province Kuroshio Current (KURO) as defined by Longhurst (1998) while clusters 2 to 4 are distributed throughout the three main provinces North Pacific Tropical Gyre (west) (NPTW), Western Pacific Warm Pool (WARM) and Archipelagic Deep Basins (ARCH) (Fig. 3).

\subsection{DMS, DMSP and DMSO concentrations in the western Pacific Ocean}

Over the entire transit the average surface seawater (i.e. $5 \mathrm{~m}$ ) concentrations for DMS as well as for dissolved DMSP $\left(\mathrm{DMSP}_{\mathrm{d}}\right)$ and DMSO $\left(\mathrm{DMSO}_{\mathrm{d}}\right)$ were $0.9,1.6$ and $4.4 \mathrm{nmol} \mathrm{L}^{-1}$, respectively. The average values for particulate DMSP $\left(\mathrm{DMSP}_{\mathrm{p}}\right)$ and DMSO $\left(\mathrm{DMSO}_{\mathrm{p}}\right)$ were 2 and $11.5 \mathrm{nmol} \mathrm{L}^{-1}$, respectively (Table 1 ). Highest concentrations for all sulphur compounds were measured when approaching the coasts of Japan and Australia (Fig. 1). The concentrations measured during this cruise were lower than the average surface measurements of DMS $\left(1.8 \mathrm{nmol} \mathrm{L}^{-1}\right)$, $\operatorname{DMSP}_{\mathrm{d}}\left(5.9 \mathrm{nmol} \mathrm{L}^{-1}\right)$, and DMSP $\mathrm{p}\left(16.2 \mathrm{nmol} \mathrm{L}^{-1}\right)$ based on data collected between 1987 and 2004 in the upper $6 \mathrm{~m}$ of the western Pacific Ocean (data retrieved from the Global Surface Seawater DMS Database: http://saga.pmel.noaa.gov/ $\mathrm{dms})$. The climatology of DMS concentrations published by Lana et al. (2011) shows a lack of October data from the tropical western Pacific (i.e. Longhurst provinces NPTW and WARM, see Fig. 3). For the Longhurst provinces KURO, ARCH and AUSE (East Australian Coastal; see Fig. 3) the mean October concentrations of DMS of the climatological predictions are given as $\sim 1, \sim 5$ and $\sim 4 \mathrm{nmol} \mathrm{L}^{-1}$, respectively (Lana et al., 2011). The differences between the climatological data and the data from our cruise might be caused by interannual variability and a general mismatch between climatological means and in situ data. The increased DMS concentrations found off the Australian coast are in agreement with the previous finding that the Great Barrier Reef is a site of enhanced production of DMS (Fischer and Jones, 2012).

The DMSO concentrations presented here are in agreement with the few published measurements of DMSO from the open Pacific Ocean, which range from 4 to $20 \mathrm{nmol} \mathrm{L}^{-1}$, and DMSO measurements from the coastal areas of the Pacific Ocean, which can reach values of up to $181 \mathrm{nmol} \mathrm{L}^{-1}$ (see overview in Hatton et al., 2005). 
Table 1. DMS, DMSP and DMSO (nmol L $\left.{ }^{-1}\right)$ and TChl $a\left(\mathrm{mg} \mathrm{m}^{-3}\right)$ concentrations as well as DMS, DMSP and DMSO versus TChl $a$ $\left(\mathrm{nmol} \mathrm{mg} \mathrm{m}^{-1}\right)$ for the entire transit and for clusters 2 and 4 . The errors given in \pm present standard deviations calculated according to David (1951). TChl $a$ errors were $2 \%$.

\begin{tabular}{|c|c|c|c|c|c|c|c|c|}
\hline & $\begin{array}{l}\text { DMS } \\
\text { average } \\
\text { range }\end{array}$ & $\begin{array}{l}\mathrm{DMSP}_{\mathrm{d}} \\
\text { average } \\
\text { range }\end{array}$ & $\begin{array}{l}\mathrm{DMSP}_{\mathrm{p}} \\
\text { average } \\
\text { range }\end{array}$ & $\begin{array}{l}\mathrm{DMSP}_{\mathrm{t}} \\
\text { average } \\
\text { range }\end{array}$ & $\begin{array}{l}\mathrm{DMSO}_{\mathrm{d}} \\
\text { average } \\
\text { range }\end{array}$ & $\begin{array}{l}\mathrm{DMSO}_{\mathrm{p}} \\
\text { average } \\
\text { range }\end{array}$ & $\begin{array}{l}\mathrm{DMSO}_{\mathrm{t}} \\
\text { average } \\
\text { range }\end{array}$ & $\begin{array}{l}\text { TChl } a \\
\text { average } \\
\text { range }\end{array}$ \\
\hline \multirow[t]{2}{*}{ transit } & $0.88 \pm 0.2$ & $1.57 \pm 0.4$ & $2.04 \pm 0.5$ & $4.01 \pm 0.7$ & $4.42 \pm 0.5$ & $11.46 \pm 2.3$ & $15.50 \pm 2.3$ & 0.21 \\
\hline & $0.26-2.85$ & $0.22-6.54$ & $0.03-7.53$ & $1.22-15.07$ & $1.81-8.06$ & $1.12-72.05$ & $3.07-76.49$ & $0.05-1.11$ \\
\hline \multirow[t]{2}{*}{ cluster 2} & $0.78 \pm 0.1$ & $1.38 \pm 0.4$ & $2.32 \pm 0.5$ & $4.12 \pm 0.6$ & $4.54 \pm 0.5$ & $10.74 \pm 1.2$ & $14.74 \pm 1.9$ & 0.18 \\
\hline & $0.26-1.25$ & $0.54-2.57$ & $0.03-7.53$ & $1.22-8.73$ & $1.81-7.82$ & $2.01-22.5$ & $3.07-25$ & $0.08-0.38$ \\
\hline \multirow[t]{3}{*}{ cluster 4} & $0.99 \pm 0.3$ & $1.10 \pm 0.3$ & $1.08 \pm 0.4$ & $2.81 \pm 0.5$ & $4.26 \pm 0.5$ & $8.11 \pm 1.0$ & $12.11 \pm 1.5$ & 0.08 \\
\hline & $0.5-2.85$ & $0.22-1.83$ & $0.05-2.67$ & $1.48-5.04$ & $2.5-6.13$ & $1.12-16.88$ & $4.18-20.71$ & $0.05-1.11$ \\
\hline & $\begin{array}{l}\text { DMS : TChl } a \\
7.54\end{array}$ & $\begin{array}{l}\operatorname{DMSP}_{\mathrm{d}}: \text { TChl } a \\
10.72\end{array}$ & $\begin{array}{l}\operatorname{DMSP}_{\mathrm{p}}: \text { TChl } a \\
12.39\end{array}$ & $\begin{array}{l}\operatorname{DMSP}_{\mathrm{t}}: \text { TChl } a \\
27.65\end{array}$ & $\begin{array}{l}\text { DMSO }_{\mathrm{d}}: \text { TChl } a \\
35.84\end{array}$ & $\begin{array}{l}\operatorname{DMSO}_{\mathrm{p}}: \text { TChl } a \\
74.92\end{array}$ & $\begin{array}{l}\text { DMSO }_{t}: \text { TChl } a \\
108.53\end{array}$ & \\
\hline transit & $1.01-39.48$ & $2.12-44.83$ & $0.12-52.44$ & $2.88-60.85$ & $3.59-104.79$ & $8.92-215.98$ & $13.99-237.26$ & \\
\hline \multirow[t]{2}{*}{ cluster 2} & 5.08 & 8.57 & 13.62 & 24.97 & 29.42 & 62.99 & 89.46 & \\
\hline & $1.47-16.08$ & $2.45-19.31$ & $0.12-52.44$ & $6.68-60.85$ & $8.1-69.59$ & $14.7-128.34$ & $13.99-154.67$ & \\
\hline \multirow[t]{2}{*}{ cluster 4} & 14.00 & 15.20 & 13.65 & 38.14 & 60.18 & 112.70 & 169.70 & \\
\hline & $5.96-39.48$ & $3.27-24.26$ & $0.61-24.78$ & $20.22-58.24$ & $24.35-104.79$ & $8.92-215.98$ & $33.27-237.26$ & \\
\hline
\end{tabular}

\subsection{Linear regressions between sulphur compounds}

In this section and those that follow, correlations (linear regressions and multiple linear regressions) between sulphur compounds, phytoplankton pigments and methane are described. We are aware that correlations do not necessarily indicate causal relationships. However, they do illustrate interactions between the tested parameters, which hint at where further investigation may be fruitful. Therefore, we describe the significant correlations found and propose explanations for the possible relationships. These explanations are based on the current knowledge of the marine sulphur cycle and proof for these hypotheses requires further investigation.

We found a positive correlation between $\mathrm{DMSP}_{\mathrm{t}}$ and DMSO $_{\mathrm{t}}\left(R^{2}=0.47, n=104, p=<0.001\right.$, Fig. 4) as well as DMSP $_{\mathrm{p}}$ and $\mathrm{DMSO}_{\mathrm{p}}\left(R^{2}=0.41, n=85, p=<0.001\right.$, Fig. 4). This is in agreement with the finding of Simó and Vila-Costa (2006b) who also reported a correlation between $\mathrm{DMSP}_{\mathrm{p}}$ and $\mathrm{DMSO}_{\mathrm{p}}$ and concluded that both compounds have the same source, namely phytoplankton. A strong link between the DMSP and DMSO pool were also found in several studies elsewhere (Lee and De Mora, 1999 and references therein). They referred to a possible direct biosynthesis of DMSO in algae cells and doubt DMS oxidation as the sole source of DMSO in the ocean.

No correlation was found between DMS and DMSO, which is in contrast to the finding by Hatton et al. (1999, 2005) who attributed the correlation to photochemical and/or bacterial oxidation of DMS to DMSO in the water column (Hatton, 2002). However, the oxidation of DMS as a source for DMSO in the western Pacific Ocean cannot be excluded: a significant positive correlation was found between $\mathrm{DMSP}_{\mathrm{d}}$ and $\mathrm{DMSO}_{\mathrm{p}}\left(R^{2}=0.35, n=102, p=<0.001\right.$, Fig. 4) as well as between DMSP $_{\mathrm{d}}$ and $\mathrm{DMSO}_{\mathrm{t}}\left(R^{2}=0.33, n=105\right.$, $p=<0.001$, Fig. 4) which may suggest that DMS, as an intermediate of the transformation of $\mathrm{DMSP}_{\mathrm{d}}$ to DMSO, is rapidly oxidised.

\subsection{Relationship between sea surface temperature and DMSP $_{p}:$ DMSO $_{p}$ ratio}

A negative correlation between sea surface temperature (SST) and the DMSP ${ }_{\mathrm{p}}: \mathrm{DMSO}_{\mathrm{p}}$ ratio was found by Simó and Vila-Costa (2006a) based on a compilation of data from various oceanic regions (mainly from the North Atlantic Ocean and its adjacent marginal seas). On the basis of the data listed in Simó and Vila-Costa (2006a), we recalculated mean $\mathrm{DMSP}_{\mathrm{p}}: \mathrm{DMSO}_{\mathrm{p}}$ ratios as well as mean SST for the various campaigns. In addition, we added other data: from the East China Sea (ratio: $0.27,17.2^{\circ} \mathrm{C}$ ) (Yang and Yang, 2011), the northern Baffin Bay (ratio: 0.20, estimated $0^{\circ} \mathrm{C}$ ) (Bouillon et al., 2002), the average $\mathrm{DMSP}_{\mathrm{p}}: \mathrm{DMSO}_{\mathrm{p}}$ ratio $(0.22 \pm 0.27)$ and the average $\operatorname{SST}\left(28.3 \pm 2.7^{\circ} \mathrm{C}\right)$ computed from the measurements during the transit presented here (Fig. 5). In agreement with Simó and VilaCosta (2006a) we found a significant negative linear correlation between $\mathrm{DMSP}_{\mathrm{p}}: \mathrm{DMSO}_{\mathrm{p}}$ ratios and SST for the temperature range $5-28^{\circ} \mathrm{C}\left(R^{2}=0.61\right)$. Moreover, a positive correlation $\left(R^{2}=0.67\right)$ was also visible in the SST range, $<10^{\circ} \mathrm{C}$, indicating that there seems to be a maximum of $\mathrm{DMSP}_{\mathrm{p}}: \mathrm{DMSO}_{\mathrm{p}}$ ratios at approximately $5-10^{\circ} \mathrm{C}$. This is in line with the observations that blooms of coccolithophorids (major DMSP producers; Simó, 2001) usually occur in high (subpolar) latitudes at SST around $9^{\circ} \mathrm{C}\left(3-15^{\circ} \mathrm{C}\right)$ (IglesiasRodriguez et al., 2002).

Our findings are in line with the argumentation of Simó and Vila-Costa (2006a) who proposed that (i) in warm waters DMSO enriched nano- and picoplankton are dominating the phytoplankton community (indeed we found that nano- and picoplankton were dominant during the transit, see Sect. 3.1), 

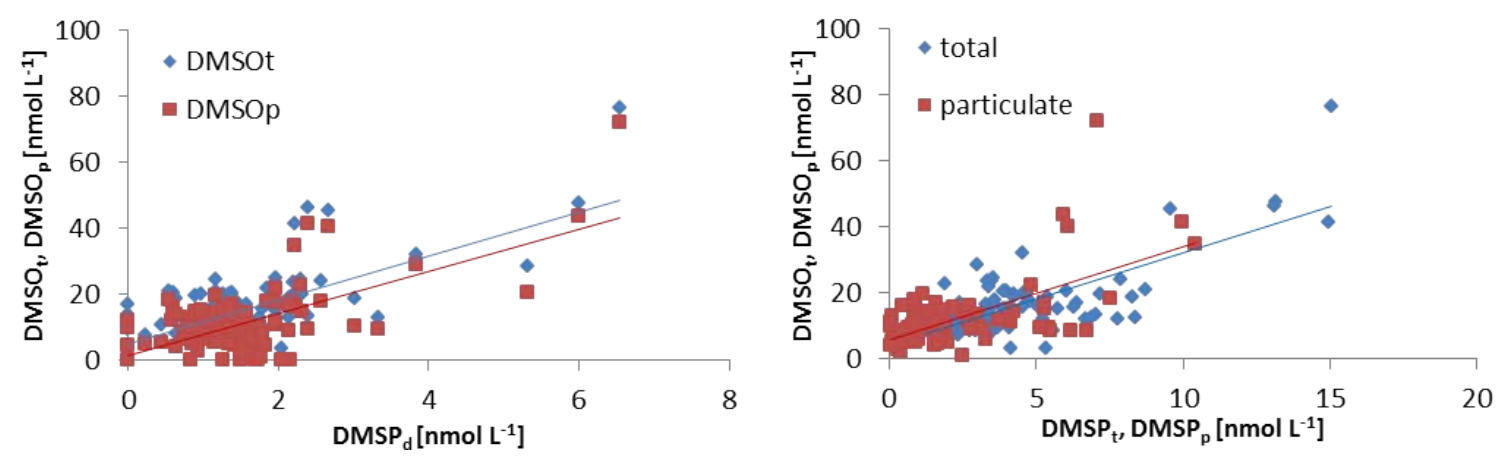

Fig. 4. Left panel: linear regression between $\mathrm{DMSP}_{\mathrm{d}}$ and $\mathrm{DMSO}_{\mathrm{t}}: y=6.66 x+5.06, R^{2}=0.33, p$ value: $1.414 \mathrm{e}^{-10}, F$ statistic: 50.86 , $n=105$, and between $\mathrm{DMSP}_{\mathrm{d}}$ and $\mathrm{DMSO}_{\mathrm{p}}: R^{2}=0.35, y=6.41 x+1.42, p$ value: $6.493 \mathrm{e}^{-11}, F$ statistic: $53.53, n=102$, both regressions for the entire data set. Right panel: linear regression between $\mathrm{DMSP}_{\mathrm{t}}$ and $\mathrm{DMSO}_{\mathrm{t}}: y=2.84 x+4.28, R^{2}=0.47, p$ value: $9.613 \mathrm{e}^{-16}$, $F$ statistic: $90.87, n=104$ and between $\mathrm{DMSP}_{\mathrm{p}}$ and $\mathrm{DMSO}_{\mathrm{p}}, y=2.84 x+5.68, R^{2}=0.41, p$ value: $5.849 \mathrm{e}^{-11}, F$ statistic: $56.54, n=85$, both regressions for the entire data set.

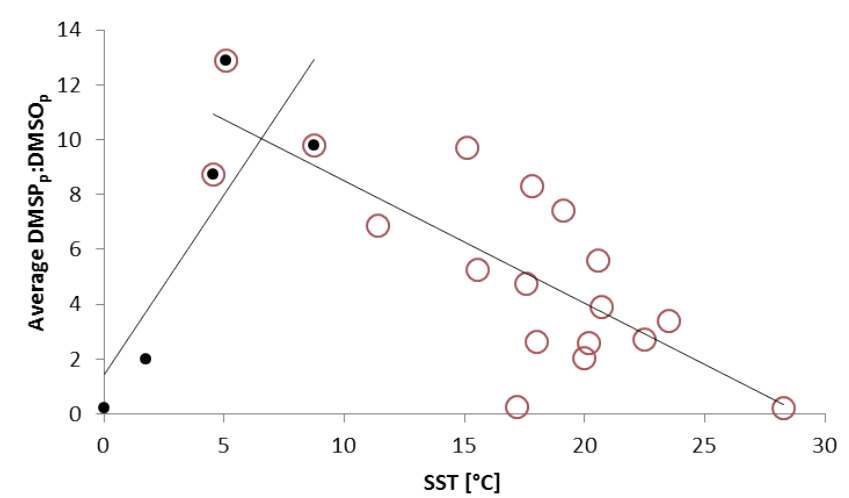

Fig. 5. Average $\mathrm{DMSP}_{\mathrm{p}}$ : $\mathrm{DMSO}_{\mathrm{p}}$ ratios vs $\mathrm{SST}$. Mean ratios for individual campaigns are recalculated from the data listed in Simó and Vila-Costa (2006a). We added data points consisting of the

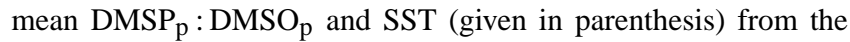
East China Sea $\left(0.27,17.2^{\circ} \mathrm{C}\right.$ ) (Yang and Yang, 2011), the northern Baffin Bay $\left(0.20\right.$, estimated $0^{\circ} \mathrm{C}$ ) (Bouillon et al., 2002) and the western Pacific Ocean $\left(0.22,28^{\circ} \mathrm{C}\right)$ (this study). The linear correlations are $y=-0.445 x+12.96\left(R^{2}=0.61\right.$, open circles $)$ and $y=1.312 x+1.44\left(R^{2}=0.67\right.$, solid circles $)$.

and (ii) high SST could be associated with surface waters receiving a high solar radiation dose, which triggers a cascade reaction system, including enhanced DMSO production, as a response to nutrient limitation and oxidative stress (Sunda et al., 2002).

\subsection{Interactions between sulphur compounds explained by multiple linear regression models (MLRM)}

In order to find further statistically significant interactions between the different sulphur compounds, MLRM were used. The MLRM calculations were performed either with the entire data set or with a subset of cluster 2 and cluster 4 data, respectively. Both clusters 2 and 4 were characterized by low biomass and were mainly dominated by cyanobacteria like prochlorophytes, which are not known to be DMSP producers (Keller et al., 1989). This resulted in low DMS and DMSP concentrations (see Sect. 3.2, Fig. 1). In the following sections we discuss the main results of the MLRM (see Table 2). The complete MLRM results are given in the Supplement (Table 1).

\subsubsection{DMS}

Over the entire transit, the DMS concentration is influenced by the $\mathrm{DMSP}_{\mathrm{p}}$ and $\mathrm{DMSO}_{\mathrm{p}}$ distribution $\left(R^{2}=0.32\right.$, Table 2 , a). It is possible that the DMS concentration was coupled to particulate DMSP and DMSO through the antioxidation system in algae cells (Sunda et al., 2002). It is most likely that in the tropical waters of the western Pacific Ocean the radiative stress on phytoplankton was enhanced. Furthermore, Spiese et al. (2009) suggested that the ability of marine phytoplankton to reduce DMSO to DMS is ubiquitous. This mechanism might be an additional explanation for the link between DMS and DMSO in the western Pacific Ocean. Within the clusters 2 and 4 all sulphur compounds have an influence on the DMS pool (Table 1, Supplement).

\subsubsection{DMSP}

A link between DMSP ${ }_{\mathrm{d}}$ and the DMSO pool during the entire transit could be found $\left(R^{2}=0.32\right.$, Table $\left.2, \mathrm{~d}\right)$. A similar source for both compounds in certain algae species might explain the link between these compounds. The MLRM showed, especially in the clusters 2 and 4, that all sulphur compounds correlated with the DMSP $\mathrm{d} / \mathrm{p}$ pool (Table 1, Supplement). This is in line with several studies that referred to the fast cycling, within a few hours, between the different sulphur compounds (Simó, 2004; Stefels et al., 2007). 
Table 2. Significant multiple linear regressions between DMS, DMSP and DMSO ( $d=$ dissolved, $p=$ particulate, $t=$ total $)$ for the entire data set and within the clusters 2 and 4 . Single coefficients and $p$ values of each multiple linear regression model as well as $R^{2}$, $F$ statistic and $p$ value of each entire model are given. The response variable is given under the model number. The independent variable squared shows a quadratic relationship to the response variable. The complete output of all models is given in the Supplement (the data presented here is extracted from Table 1 in the Supplement).

\begin{tabular}{|c|c|c|c|}
\hline $\begin{array}{l}\text { model } \\
\text { no. }\end{array}$ & $\begin{array}{l}\text { single } \\
\text { coefficients }\end{array}$ & $\begin{array}{l}p \\
\text { value }\end{array}$ & $\begin{array}{l}R^{2}, F \text { st., } \\
p \text { value (e.m.) }\end{array}$ \\
\hline $\begin{array}{l}\text { a } \\
\text { DMS } \\
\text { e.d.s. }\end{array}$ & $\begin{array}{l}\text { DMSPp } \\
\text { DMSOp }\end{array}$ & $\begin{array}{l}2.36 \times 10^{-9} \\
1.49 \times 10^{-7}\end{array}$ & $\begin{array}{l}0.32 \\
24.57 \\
1.83 \times 10^{-9}\end{array}$ \\
\hline $\begin{array}{l}\text { d } \\
\text { DMSPd } \\
\text { e.d.s. }\end{array}$ & $\begin{array}{l}\operatorname{DMSOp}^{\wedge} 2 \\
\operatorname{DMSOd}^{\wedge} 2 \\
\text { DMSPp:DMSOp }\end{array}$ & $\begin{array}{l}1.14 \times 10^{-7} \\
0.02 \\
3.27 \times 10^{-4}\end{array}$ & $\begin{array}{l}0.32 \\
16.22 \\
1.084 \times 10^{-8}\end{array}$ \\
\hline $\begin{array}{l}\text { i } \\
\text { DMSOd } \\
\text { e.d.s. }\end{array}$ & $\begin{array}{l}\text { DMSPd } \\
\operatorname{DMS}^{\wedge} 2 \\
\operatorname{DMSPd}^{\wedge} 2\end{array}$ & $\begin{array}{l}0.04 \\
5.13 \times 10^{-5} \\
0.03\end{array}$ & $\begin{array}{l}0.19 \\
8.05 \\
7.26 \times 10^{-5}\end{array}$ \\
\hline $\begin{array}{l}\mathrm{j} \\
\text { DMSOd } \\
\text { cluster } 2\end{array}$ & $\begin{array}{l}\text { DMSPp } \\
\text { DMSPd } \\
\text { DMSPp }^{\wedge} 2 \\
\text { DMSPp:DMSPd }\end{array}$ & $\begin{array}{l}0.03 \\
0.01 \\
0.05 \\
0.005\end{array}$ & $\begin{array}{l}0.28 \\
4.82 \\
0.002\end{array}$ \\
\hline $\begin{array}{l}\mathrm{k} \\
\text { DMSOd } \\
\text { cluster } 4\end{array}$ & $\begin{array}{l}\text { DMSPp } \\
\text { DMSOp } \\
\text { DMSPp:DMSOp }\end{array}$ & $\begin{array}{l}0.001 \\
0.004 \\
0.002\end{array}$ & $\begin{array}{l}0.35 \\
4.59 \\
0.01\end{array}$ \\
\hline $\begin{array}{l}1 \\
\text { DMSOp } \\
\text { e.d.s. }\end{array}$ & $\begin{array}{l}\text { DMSPd } \\
\text { DMSPp }\end{array}$ & $\begin{array}{l}5.61 \times 10^{-7} \\
6.72 \times 10^{-8}\end{array}$ & $\begin{array}{l}0.43 \\
36.53 \\
1.49 \times 10^{-12}\end{array}$ \\
\hline $\begin{array}{l}\mathrm{n} \\
\text { DMSOp } \\
\text { cluster } 4\end{array}$ & $\begin{array}{l}\text { DMS } \\
\text { DMSPd } \\
\text { DMSPp }\end{array}$ & $\begin{array}{l}0.06 \\
0.05 \\
1.26 \times 10^{-4}\end{array}$ & $\begin{array}{l}0.46 \\
7.23 \\
0.001\end{array}$ \\
\hline
\end{tabular}

Abbr.: st.: statistic; e.m.: entire model; e.d.s.: entire data set; a-m: number of models

\subsubsection{DMSO}

The MLRM showed that DMSP $\mathrm{d}_{\mathrm{d}}$ and DMS influenced the $\mathrm{DMSO}_{\mathrm{d}}$ pool during the entire transit $\left(R^{2}=0.19\right.$, Table 2, i). It is most likely that $\mathrm{DMSO}_{\mathrm{d}}$ is directly produced due to the oxidation of DMS in the water column (Hatton et al., 2005). $\mathrm{DMSP}_{\mathrm{d}}$ might be used by free living bacteria in the water column as a substrate to produce DMSO. Additionally, DMSP $_{d}$ could be converted to DMS by bacteria, which can contribute to the DMS pool. However, these processes might be of minor importance because it only explains $19 \%$ of the $\mathrm{DMSO}_{\mathrm{d}}$ distribution. Thus, other factors are probably more important for the $\mathrm{DMSO}_{\mathrm{d}}$ concentration, such as direct synthesis in algae cells and release into the water column (Simó et al., 1998), and photo-oxidation of DMS to DMSO (Hatton et al., 1996).
In cluster $2, \mathrm{DMSO}_{\mathrm{d}}$ seemed to be dependent only on the DMSP pool $\left(R^{2}=0.28\right.$, Table $\left.2, \mathrm{j}\right)$, while in cluster $4, \mathrm{DMSP}_{\mathrm{p}}$ and $\mathrm{DMSO}_{\mathrm{p}}$ were significant contributors $\left(R^{2}=0.35\right.$, Table $2, \mathrm{k}$ ). Furthermore, $\mathrm{DMSO}_{\mathrm{p}}$ was directly dependent on $\operatorname{DMSP}_{d / p}\left(R^{2}=0.43\right.$, Table 2,1$)$ over the entire transit and in the region of cluster $4\left(R^{2}=0.46\right.$, Table $\left.2, \mathrm{n}\right)$ comparable to $\mathrm{DMSO}_{\mathrm{d}}$.

These findings are in line with the direct correlations (see Sect. 3.3) and confirm the assumption of direct biosynthesis of DMSO in the phytoplankton and the possible same source of $\mathrm{DMSO}_{\mathrm{p}}$ and $\mathrm{DMSP}_{\mathrm{p}}$ in certain algae taxa. Due to the ability of DMSO to permeate easily through membranes, a coupling of $\mathrm{DMSO}_{\mathrm{d}}$ and $\mathrm{DMSO}_{\mathrm{p}}$ seems reasonable. The production of $\mathrm{DMSO}_{\mathrm{p}}$ from $\mathrm{DMSP}_{\mathrm{d}}$ may be explained by bacteria that are attached to particles and use DMSP $_{d}$ as a substrate. The statistical analysis underlines the importance of DMSO for the sulphur cycle and the tight coupling especially between DMSO and DMSP.

\subsection{Influence of phytoplankton on the DMS, DMSP and DMSO distributions in surface seawater}

Linear positive correlations between TChl $a$ and $\mathrm{DMSO}_{\mathrm{p}}$,

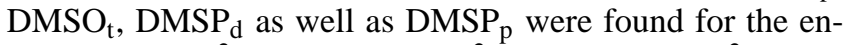
tire data set $\left(R^{2}=0.25, n=94 ; R^{2}=0.22, n=96 ; R^{2}=0.29\right.$, $n=99$; and $R^{2}=0.23, n=87$, for all $p=<0.001$, respectively). These correlations were somewhat weak, which may result from a dependency on certain algae taxon and not on phytoplankton in general for both DMSP and DMSO. In contrast, Lee et al. (1999b) found a negative correlation between $\mathrm{DMSO}_{\mathrm{p}}$ and $\mathrm{Chl} a$ in a Canadian fjord. They explained this observation with an increase in photosynthetic activity and, therefore, an increase in free radicals that reacted with DMSO. However, the correlations found in the fjord were dependent on temporal variability and on the nano- to picoplankton fraction, in contrast to the general correlations presented in this section. Thus, more detailed correlations between phytoplankton and DMSO in the western Pacific Ocean might shed more light on the possible relationships (see Sect. 3.6.3).

\subsubsection{DMS and phytoplankton groups}

The influence of a variety of phytoplankton groups on the different sulphur compounds for the entire transit and within the clusters 2 and 4 were also tested by using the MLRM. The following phytoplankton groups were tested (characteristic marker pigments are given in parenthesis): diatoms (fucoxanthin (main indicator for diatoms), diatoxanthin, diadinoxanthin (both unspecific, mainly diatoms)), dinoflagellates (peridinin), cryptophytes (alloxanthin), haptophytes (19'-hexanoyloxyfucoxanthin), chrysophytes (19'-butanoyloxyfucoxanthin), prasinophytes (prasinoxanthin), chlorophytes (violaxanthin), cromophytes (anthreaxanthin) and cyanobacteria (zeaxanthin). Chlorophyll 
pigments were not used for the calculations due to their occurrence in all phytoplankton groups.

The model showed that algae groups played a minor role for the DMS distribution over the entire transit. Only in cluster 2, diatoms, haptophytes and dinoflagellates were tested significantly for DMS $\left(R^{2}=0.32\right.$, Table 3 , a). Bürgermeister et al. (1990) and Merzouk et al. (2008) found increased DMS concentrations caused by diatoms in the Atlantic Ocean. Additionally, it is well known that elevated abundances of haptophytes and dinoflagellates are responsible for enhanced DMS concentrations. Additionally, all these algae groups were identified as important contributors to the DMSP $P_{d / p}$ pool with the MLRM in this study (see below), which indicated that DMS was probably only indirectly dependent on these algae via bacteria. This finding is in line with Yoch (2002), Kiene et al. (2000) and Schäfer et al. (2010), reporting that DMS is mainly controlled by the activity of bacterioplankton. It might be possible that DMS was rapidly converted into DMSO by bacteria that used DMS as an energy source (Boden et al., 2011; Green et al., 2011). This fast conversion could explain the low DMS concentrations and the lack of correlations between algae and DMS along the western Pacific Ocean transit.

\subsubsection{DMSP and phytoplankton groups}

Over the entire transit, the main phytoplankton groups that influenced the $\mathrm{DMSP}_{\mathrm{d}}$ distribution were dinoflagellates, chrysophytes, and cyanobacteria; although cyanobacteria are not considered to be important DMSP producers (Keller et al., 1989). In contrast, diatoms appear to be the most important algae group in cluster 2 both for $\mathrm{DMSP}_{\mathrm{d}}$ and $\mathrm{DMSP}_{\mathrm{p}}$ $\left(R^{2}=0.61\right.$, Table 3, c; $R^{2}=0.73$, Table 3 , e; respectively $)$.

Dinoflagellates, chrysophytes, and diatoms appeared to be the most important contributors to the DMSP $_{\mathrm{p}}$ pool $\left(R^{2}=0.37\right.$, Table $\left.3, \mathrm{~d}\right)$ for the entire transit. In cluster 4 no pigment was found that contributed significantly to $\operatorname{DMSP}_{\mathrm{d} / \mathrm{p}}$.

Belviso et al. (2001) showed a clear relationship between DMSP $_{\mathrm{p}}$ and haptophytes as well as chrysophytes with over 200 samples from different regions (Atlantic Ocean, Mediterranean Sea and Southern Ocean) by using linear regression. Although haptophytes were only important for $\mathrm{DMSP}_{\mathrm{p}}$, in cluster 2 chrysophytes were identified as an important algae group for all DMSP pools in this study. Dinoflagellates were identified as producers for all DMSP pools in the Pacific Ocean, which is in agreement with findings in other marine regions (Keller et al., 1989; Stefels, 2000; Steinke et al., 2002). Surprisingly, diatoms and cyanobacteria influenced DMSP, although these algae groups are generally thought to be minor DMSP producers (Keller et al., 1989). The cyanobacteria and diatoms were distributed in similar patterns to the DMSP producing taxa, possibly causing the model to identify them as contributors to the DMSP pool. It should also be considered that cyanobacteria were dom- inant in the main part of the western Pacific Ocean transit and were mainly responsible for the TChl $a$ concentration, which showed a weak correlation with DMSP. In addition, some specialized diatom species in the Pacific Ocean may also be able to produce a sizable amount of DMSP. Keller et al. (1989) showed that certain species of diatoms can be significant for the DMSP pool.

\subsubsection{DMSO and phytoplankton groups}

Diatoms, haptophytes and chrysophytes correlated significantly with $\mathrm{DMSO}_{\mathrm{d}}\left(R^{2}=0.42\right.$, Table 3 , i). In cluster 2 , dinoflagellates, diatoms and chrysophytes were the most important pigments for the $\mathrm{DMSO}_{d}$ as well as for the $\mathrm{DMSO}_{\mathrm{p}}$ distribution $\left(R^{2}=0.45\right.$, Table $3, \mathrm{j} ; R^{2}=0.84$, Table 3,1 , respectively). Furthermore, diatoms, cyanobacteria and dinoflagellates seemed to influence the $\mathrm{DMSO}_{\mathrm{p}}$ distribution for the entire data set $\left(R^{2}=0.54\right.$, Table $\left.3, \mathrm{k}\right)$. In cluster 4 no significant correlations could be found.

For DMSP and DMSO the same algae groups were identified as important sulphur producers but in different compositions dependent on the sulphur compound and the region. Field measurements conducted by Lee et al. (1999b) and culture experiments with dinoflagellates and haptophytes that showed high $\mathrm{DMSO}_{\mathrm{p}}$ production (Simó et al., 1998) suggested that $\mathrm{DMSO}_{\mathrm{p}}$ might be produced by a broad range of phytoplankton comparable to that of DMSP producing algae groups. The authors did not exclude that other species, which are not known as DMSP producers, might also be responsible for a significant amount of DMSO. In this study, we also found that $\mathrm{DMSO}_{\mathrm{p}}$ correlated with phytoplankton pigments of known DMSP producers. However, the pigment analysis did not show direct correlations between DMSO and pigments from non-DMSP producing phytoplankton. Cryptophytes, prasinophytes, chlorophytes and cromophytes showed no or negligible influence on the distribution of all tested sulphur species in the western Pacific.

Only a few correlations were found in cluster 4 compared to cluster 2 and the entire transit. Cluster 4 included mainly the oligotrophic warm waters of the western Pacific Ocean dominated by cyanobacteria. The distribution pattern of phytoplankton is similar to cluster 2 . However, cluster 4 was different from other clusters by its particularly low biomass, as well as the lowest sulphur concentrations of the entire transit (Fig. 1). It seems that the very low biomass was the main factor governing the concentrations of sulphur in this region, with a minor influence of the algae composition. Thus, large regions in the subtropical and tropical western North Pacific Ocean did not have a highly dynamic sulphur cycle in the surface ocean during the transit in October 2009.

\subsection{Sulphur compounds as precursors for methane}

The $\mathrm{CH}_{4}$ concentrations (corresponding saturations are given in parenthesis) during the cruise were in the range from 
Table 3. Significant multiple linear regressions between DMS, DMSP and DMSO $(d=$ dissolved, $p=$ particulate, $t=$ total $)$ and phytoplankton marker pigments for the entire data set and within the clusters 2 and 4. Single coefficients and $p$ values of each multiple linear regression model as well as $R^{2}, F$ statistic and $p$ value of each entire model are given. The response variable is given under the model number. The independent variable squared shows a quadratic relationship to the response variable. The complete output of all models is given in the Supplement (the data presented here is extracted from Table 2 in the Supplement).

\begin{tabular}{|c|c|c|c|c|c|c|c|}
\hline $\begin{array}{l}\text { model } \\
\text { no. }\end{array}$ & $\begin{array}{l}\text { single } \\
\text { coefficients }\end{array}$ & $\begin{array}{l}p \\
\text { value }\end{array}$ & $\begin{array}{l}R^{2}, F \text { st., } \\
p \text { value (e.m.) }\end{array}$ & $\begin{array}{l}\text { model } \\
\text { no. }\end{array}$ & $\begin{array}{l}\text { single } \\
\text { coefficients }\end{array}$ & $\begin{array}{l}p \\
\text { value }\end{array}$ & $\begin{array}{l}R^{2}, F \text { st., } \\
p \text { value (e.m.) }\end{array}$ \\
\hline a & fuco & 0.004 & 0.32 & $\mathrm{i}$ & diato & 0.03 & 0.42 \\
\hline $\begin{array}{l}\text { DMS } \\
\text { cluster } 2\end{array}$ & $\begin{array}{l}\text { hex } \\
\text { peri }^{\wedge} 2\end{array}$ & $\begin{array}{l}0.01 \\
0.003\end{array}$ & $\begin{array}{l}3.66 \\
0.005\end{array}$ & $\begin{array}{l}\text { DMSOd } \\
\text { e.d.s. }\end{array}$ & $\begin{array}{l}\operatorname{hex}^{\wedge} 2 \\
\operatorname{but}^{\wedge} 2\end{array}$ & $\begin{array}{l}1.11 \times 10^{-4} \\
9.68 \times 10^{-5}\end{array}$ & $\begin{array}{l}7.55 \\
1.65 \times 10^{-7}\end{array}$ \\
\hline $\begin{array}{l}\text { b } \\
\text { DMSPd } \\
\text { e.d.s. }\end{array}$ & $\begin{array}{l}\text { but } \\
\text { peri } \\
\text { zea }\end{array}$ & $\begin{array}{l}1.01 \times 10^{-5} \\
2.96 \times 10^{-4} \\
2.01 \times 10^{-6}\end{array}$ & $\begin{array}{l}0.44 \\
11.34 \\
2.36 \times 10^{-9}\end{array}$ & $\begin{array}{l}\mathrm{j} \\
\text { DMSOd } \\
\text { cluster } 2\end{array}$ & $\begin{array}{l}\text { peri } \\
\text { dia } \\
\text { but }\end{array}$ & $\begin{array}{l}1.24 \times 10^{-5} \\
4.38 \times 10^{-2} \\
8.61 \times 10^{-3}\end{array}$ & $\begin{array}{l}0.45 \\
10.1 \\
4.81 \times 10^{-6}\end{array}$ \\
\hline $\begin{array}{l}\text { c } \\
\text { DMSPd } \\
\text { cluster } 2\end{array}$ & $\begin{array}{l}\text { fuco } \\
\text { diato } \\
\text { but }^{\wedge} 2\end{array}$ & $\begin{array}{l}0.01 \\
0.01 \\
1.91 \times 10^{-3}\end{array}$ & $\begin{array}{l}0.61 \\
5.93 \\
1.15 \times 10^{-5}\end{array}$ & $\begin{array}{l}\mathrm{k} \\
\text { DMSOp } \\
\text { e.d. s. }\end{array}$ & $\begin{array}{l}\text { fuco } \\
\text { diato } \\
\text { zea } \\
\text { peri }^{\wedge} 2\end{array}$ & $\begin{array}{l}6.83 \times 10^{-6} \\
1.09 \times 10^{-3} \\
1.76 \times 10^{-6} \\
1.50 \times 10^{-5}\end{array}$ & $\begin{array}{l}0.54 \\
9.18 \\
8.46 \times 10^{-10}\end{array}$ \\
\hline $\begin{array}{l}\text { d } \\
\text { DMSPp } \\
\text { e.d.s. }\end{array}$ & $\begin{array}{l}\text { peri } \\
\text { but } \\
\text { fuco }\end{array}$ & $\begin{array}{l}9.88 \times 10^{-3} \\
9.23 \times 10^{-5} \\
0.05\end{array}$ & $\begin{array}{l}0.37 \\
9.3 \\
5.01 \times 10^{-8}\end{array}$ & $\begin{array}{l}1 \\
\text { DMSOp } \\
\text { cluster } 2\end{array}$ & $\begin{array}{l}\text { peri } \\
\text { diato } \\
\text { but }\end{array}$ & $\begin{array}{l}7.63 \times 10^{-3} \\
3.56 \times 10^{-3} \\
0.04\end{array}$ & $\begin{array}{l}0.84 \\
12.98 \\
1.93 \times 10^{-9}\end{array}$ \\
\hline $\begin{array}{l}\text { e } \\
\text { DMSPp } \\
\text { cluster } 2\end{array}$ & $\begin{array}{l}\text { fuco } \\
\text { diato } \\
\text { zea } \\
\text { hex }\end{array}$ & $\begin{array}{l}2.32 \times 10^{-4} \\
2.46 \times 10^{-3} \\
5.32 \times 10^{-4} \\
3.51 \times 10^{-2}\end{array}$ & $\begin{array}{l}0.73 \\
11.94 \\
4.02 \times 10^{-8}\end{array}$ & & & & \\
\hline
\end{tabular}

Abbr.: st.: statistic; e.m.: entire model; e.d.s.: entire data set; fuco: fucoxanthin; hex: $19^{\prime}$-hexanoyloxyfucoxanthin, peri: peridinin, diato: diatoxanthin,dia: diadinoxanthin, diato: diatoxanthin, but: 19'-butanoyloxyfucoxanthin;zea: zeaxanthin.

1.8 to $4.8 \mathrm{nmol} \mathrm{L}^{-1}(91-218 \%)$ with an average ( \pm standard deviation) of $2.5 \pm 0.8 \mathrm{nmol} \mathrm{L}^{-1}(127 \pm 32 \%)$. The highest $\mathrm{CH}_{4}$ concentrations $\left(3.8-4.8 \mathrm{nmol} \mathrm{L}^{-1} ; 159-218 \%\right)$ were measured at the beginning of the cruise in the cold waters of the Oyashio Current (north of $36^{\circ} \mathrm{N}$ ), followed by a decrease in $\mathrm{CH}_{4}$ concentrations of $2.8-1.8 \mathrm{nmol} \mathrm{L}^{-1}$ (142$96 \%$ ) after crossing the warm Kuroshio Current was crossed (between 36 and $25^{\circ} \mathrm{N}$ ). The lowest $\mathrm{CH}_{4}$ concentrations $\left(2.0 \pm 0.2 \mathrm{nmol} \mathrm{L}^{-1} ; 104 \pm 11 \%\right)$ were measured between the equator and $28^{\circ} \mathrm{N}$ and, thus, they were roughly associated with cluster 4 (see Sect. 3.1). The average $\mathrm{CH}_{4}$ concentrations between the equator and $19^{\circ} \mathrm{S}$ was $2.4 \pm 0.5 \mathrm{nmol} \mathrm{L}^{-1}$ $(127 \pm 26 \%)$. Thus we conclude that during the transit the ocean was an overall weak net source of $\mathrm{CH}_{4}$ to the atmosphere. Comparable mean surface $\mathrm{CH}_{4}$ concentrations of $2.5 \pm 0.3 \mathrm{nmol} \mathrm{L}^{-1}$ and $2.2 \pm 0.02 \mathrm{nmol} \mathrm{L}^{-1}$ were measured along $165^{\circ} \mathrm{E}$ between $40^{\circ} \mathrm{N}$ and $5^{\circ} \mathrm{S}$ and in the Kuroshio Current waters $\left(27-30^{\circ} \mathrm{N}, 133-142^{\circ} \mathrm{E}\right)$, respectively, by Watanabe et al. (1995). Rehder and Suess (2001) measured $\mathrm{CH}_{4}$ surface concentrations in the range from 2.5 to $5 \mathrm{nmol} \mathrm{L}^{-1}$ between 38.6 and $42^{\circ} \mathrm{N}$ in the Tsugaro Current outflow/Oyashio Current mixing region with a decrease in $\mathrm{CH}_{4}$ concentrations to $2.3 \mathrm{nmol} \mathrm{L}^{-1}$ when Kuroshio Cur- rent waters were measured in the coastal waters off Honshu further south. Moreover, Bates et al. (1996) reported $\mathrm{CH}_{4}$ concentrations between 1.6 and $3.6 \mathrm{nmol} \mathrm{L}^{-1}$ for a series of five latitudinal transects in the Pacific Ocean.

We found a significant positive correlation between TChl $a$ and $\mathrm{CH}_{4}$ surface concentrations $\left(R^{2}=0.69, p=<0.001\right.$, $n=36$, Fig. 6). There are only a few other studies that report a correlation between Chl $a$ and $\mathrm{CH}_{4}$ (Owens et al., 1991; Damm et al., 2008). Watanabe et al. (1995) found a general trend but no significant correlation along $165^{\circ} \mathrm{E}$. Since the majority of the studies did not find a correlation between $\mathrm{Chl} a$ and $\mathrm{CH}_{4}$ and direct evidence from lab experiments with (axenic) algae cultures has not been published yet, it is widely accepted that the accumulation of $\mathrm{CH}_{4}$ in the upper open ocean is not related to a direct production by algae.

In our study, significant positive linear correlations were found between $\mathrm{DMSO}_{\mathrm{p}}$ and $\mathrm{CH}_{4}\left(R^{2}=0.37, p=<0.001\right.$, $n=31)$ and $\mathrm{DMSO}_{\mathrm{t}}$ and $\mathrm{CH}_{4} \quad\left(R^{2}=0.42, p=<0.001\right.$, $n=33)$, as well as between $\mathrm{DMSP}_{\mathrm{d}}$ and $\mathrm{CH}_{4}\left(R^{2}=0.57\right.$, $p=<0.001, n=35$ ) for the entire north-south transit (Fig. 7). Additionally, we found a good correlation between $\mathrm{CH}_{4}$ and the marker pigment for chrysophyceae $\left(R^{2}=0.76\right.$, $p=<0.001, n=36$, Fig. 6), which are known as DMSP 


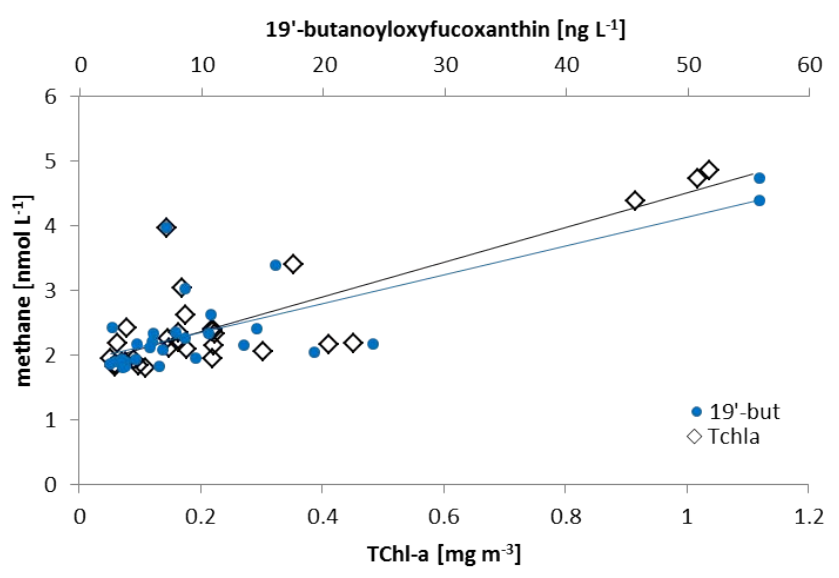

Fig. 6. Linear regression between TChl $a$ and methane $(y=$ $0.0027 x+1.82, R^{2}=0.69, F$ statistic: $63, p$ value $<0.001, n=36$, open diamonds) and between chrysophytes (indicated by marker pigments $19^{\prime}$ - butanoyloxyfucoxanthin, upper x-axis) and methane $\left(y=0.044 x+1.92, R^{2}=0.76, F\right.$ statistic: $80, p$ value: $<0.001$, $n=36$, solid circles).

producers (Belviso et al., 2001) and which were correlated with $\mathrm{DMSP}_{\mathrm{d}}$ and $\mathrm{DMSO}_{\mathrm{t}}$ in our study (see Sects. 3.6.2 and 3.6.3). Therefore, we conclude that algae derived DMSP and DMSO might be considered as possible precursors for $\mathrm{CH}_{4}$ production in the western Pacific Ocean. However, further direct evidence is necessary to support this suggestion.

Damm et al. (2008) showed a significant negative correlation between $\mathrm{DMSP}_{\mathrm{t}}$ and $\mathrm{CH}_{4}\left(R^{2}=0.55\right)$ in the surface waters of an Arctic shelf region (Storfjorden, Svalbard Archipelago), which is in contrast to the positive correlation with $\mathrm{DMSP}_{\mathrm{d}}$ found in our study. Moreover, we could not find any correlation between $\mathrm{DMSP}_{\mathrm{t}}$ and $\mathrm{CH}_{4}$ in our data from the western Pacific Ocean. Thus, there are obvious differences between the results from the Storfjorden and the western Pacific Ocean (despite the fact that the conclusions are the same): the algal community in the western Pacific Ocean during our cruise was very likely suffering from continuous oxidative stress and nutrient limitation, which could have led to a continuous production of DMSP $_{p}$ (Sunda et al., 2002), and thus, DMSP$P_{d}$. This, in turn, implies a continuous formation of $\mathrm{CH}_{4}$ from $\mathrm{DMSP}_{\mathrm{d}}$ via the demethylation of methyl-mercaptoprpionate (MMPA) to mercaptoprpionate (MPA) and methane due to methanogenic archaea (van der Maarel and Hansen, 1997) and may explain the positive correlation between the $\mathrm{DMSP}_{\mathrm{d}}$ and $\mathrm{CH}_{4}$. In contrast, a bloom situation was encountered in the Storfjorden, which implies that the algae did not suffer from oxidative stress and/or nutrient limitation and therefore a continuous production of DMSP was not necessary. The negative correlation found in Storfjorden might have been caused by the fact that $\mathrm{CH}_{4}$ had been produced from intermediates resulting from a DMSP pool that was not replenished at the time of the bloom. Additionally, it should be noted that Damm et al. (2008) observed

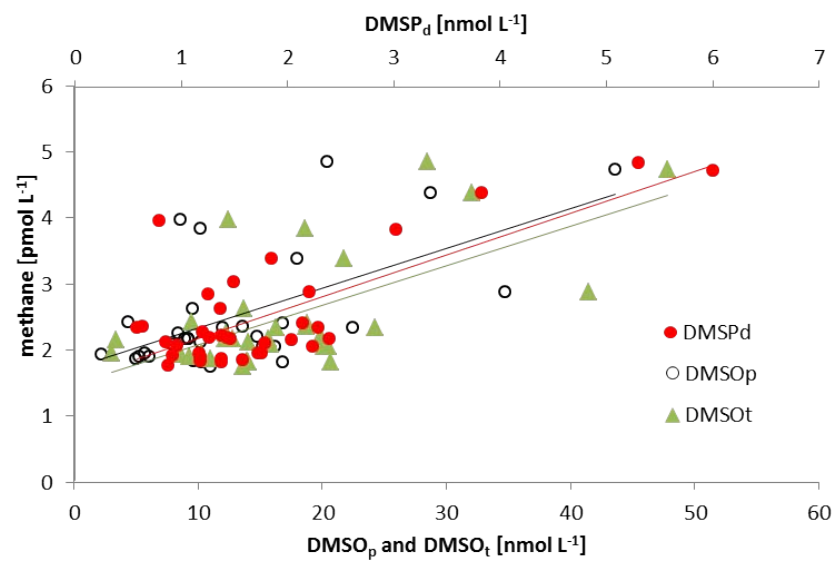

Fig. 7. Relationship between the sulphur compounds $\left(\mathrm{DMSP}_{\mathrm{d}}\right.$, $\left.\mathrm{DMSO}_{\mathrm{p}} \mathrm{DMSO}_{\mathrm{t}}\left(\mathrm{nmolL} \mathrm{L}^{-1}\right)\right)$ and methane $\left(\mathrm{nmol} \mathrm{L}^{-1}\right)$ in the surface water of the north-south transit in the western Pacific Ocean. DMSP $_{\mathrm{d}}$ vs methane: $y=0.55 x+1.54, R^{2}=0.57, F$ statistic: 43.08 , $p$ value: $1.85 \mathrm{e}^{-7}, n=36$; DMSO $_{\mathrm{p}}$ vs methane: $y=0.06 x+1.72$, $R^{2}=0.37, F$ statistic: $17.25, p$ value: $2.64 \mathrm{e}^{-4}, n=31 ; \mathrm{DMSO}_{\mathrm{t}}$ vs methane: $y=0.06 x+1.48, R^{2}=0.42, F$ statistic: $22.49, p$ value: $4.5 \mathrm{e}-05, n=33$.

increasing $\mathrm{CH}_{4}$ concentrations when $\mathrm{DMSP}_{\mathrm{t}}$ concentrations were $>5 \mathrm{nmol} \mathrm{L}^{-1}$ but could see no effect on the $\mathrm{CH}_{4}$ concentrations when DMSP $\mathrm{t}_{\mathrm{t}}$ levels were $<5 \mathrm{nmol} \mathrm{L}^{-1}$. In our study, however, a correlation between $\mathrm{DMSP}_{\mathrm{d}}$ and $\mathrm{CH}_{4}$ was found although the concentrations for both compounds were much lower. This reflects less intensive biological activity, perhaps due to different assemblages of bacterioplankton, physiological stages of the bacteria and/or nutrient limitation and oxidative stress compared to Storfjorden.

A negative correlation between $\mathrm{CH}_{4}$ and $\mathrm{DMSP}_{\mathrm{t}}$ was also found in phosphate enriched, but nitrate depleted, oligotrophic Arctic Ocean waters originating from the Pacific Ocean. This indicates that $\mathrm{CH}_{4}$ production from $\mathrm{DMSP}_{\mathrm{t}}$ degradation products in oligotrophic Arctic waters is mainly dependent on the availability of phosphate (Damm et al., 2010). Despite the fact that nutrient data are not available for the TransBrom cruise, it is reasonable to assume that the surface waters in the western tropical Pacific Ocean during TransBrom were depleted in both phosphate and nitrate (see e.g. World Ocean Atlas of the National Oceanographic Data Center: http://www.nodc.noaa.gov/ OC5/SELECT/woaselect/woaselect.html). Thus, the $\mathrm{CH}_{4}$ production from DMSP degradation products in the western Pacific Ocean seems to be derived from a different mechanism than the one found in Arctic waters.

In a microcosm experiment conducted in the central Arctic, three main proteobacteria groups were identified as possible $\mathrm{CH}_{4}$ producers, which seemed to have produced $\mathrm{CH}_{4}$ (indirectly) by degradation of DMSP (Damm et al., 2010): Rhodobacter, Sulfitobacter (both in the family Rhodobacteraceae) and Mesorhizobium types. It is noteworthy that 
bacteria of Rhodobacteraceae are widespread in the oligotrophic oceans and have genes that metabolize DMSP (Moran et al., 2003, 2007, 2012). Therefore, we think it is possible that these bacteria groups could have been responsible for the $\mathrm{CH}_{4}$ production along the north-south transit in the Pacific Ocean. However, this needs to be proven directly by conducting experiments with these bacteria groups in lab culture experiments.

For the first time a correlation between DMSO and $\mathrm{CH}_{4}$ could be observed in surface ocean waters. There are two possible pathways: (1) DMSO was reduced to DMS (Hatton et al., 2005; Spiese et al., 2009), which, in turn, may act as a precursor for $\mathrm{CH}_{4}$ and (2) a direct (biological or nonbiological) production of $\mathrm{CH}_{4}$ from DMSO. However, microbial production of $\mathrm{CH}_{4}$ from DMS as well as a chemical production of $\mathrm{CH}_{4}$ via reaction of $\mathrm{OH}$ with $\mathrm{DMSO}_{\mathrm{d}}$ (Eberhardt and Colina, 1988) are known to occur only under anoxic conditions. Thus, the exact pathway and mechanism of $\mathrm{CH}_{4}$ production from DMSO in the oxic surface layer remains to be proven. If DMSO is a potential precursor or substrate for the marine $\mathrm{CH}_{4}$ production, the influence of DMSO on the $\mathrm{CH}_{4}$ pool in the deep oceans is underestimated because of the widespread distribution of DMSO throughout the entire water column (Bouillon et al., 2002; Hatton et al., 1999).

\section{Summary}

Along the north-south transit of the TransBrom cruise, the western Pacific Ocean contained low biomass except in the cold Oyashio Current waters, in coastal regions in the vicinity of islands and the Great Barrier Reef. The low biomass regions were dominated by picoplankton, with prochlorophytes dominating. In high TChl $a$ regions, haptophytes contributed significantly to the biomass.

For the first time a DMSO distribution pattern was presented in surface seawater along a north-south transit in the western Pacific Ocean. Correlations between DMSO and DMSP, as well as DMSO and DMSP with TChl $a$, were observed during the entire transit, suggesting a similar source for both sulphur species, namely biosynthesis in specialized algae. Several algae groups were identified as contributors to the DMSP and DMSO pool, mostly haptophytes, chrysophytes and dinoflagellates. Diatoms were also identified although they are not known to be significant sulphur producers. DMSP and DMSO seemed to be influenced by largely the same algae species, indicating that DMSP producing algae might have the potential to synthesise DMSO as well.

The observed $\mathrm{DMSP}_{\mathrm{p}}: \mathrm{DMSO}_{\mathrm{p}}$ ratios were extremely low and generally $<1$. They seem to be characteristic for oligotrophic tropical waters representing the extreme endpoint of the global DMSP ${ }_{\mathrm{p}}: \mathrm{DMSO}_{\mathrm{p}}$ ratio vs SST relationship. It is most likely that nutrient limitation and oxidative stress in the tropical western Pacific Ocean led to enhanced DMSO production.

$\mathrm{DMSP}_{\mathrm{d}}$ and $\mathrm{DMSO}_{\mathrm{p} / \mathrm{t}}$ were positively correlated with $\mathrm{CH}_{4}$ during the entire north-south transit, although the concentrations of both sulphur compounds and $\mathrm{CH}_{4}$ were low. We conclude that DMSP could be considered as a potential precursor for $\mathrm{CH}_{4}$ production in the surface waters of the western Pacific Ocean. For the first time we have shown that DMSO might act as a precursor or substrate for $\mathrm{CH}_{4}$ production as well. However, further studies are necessary to understand how sulphur compounds are converted into $\mathrm{CH}_{4}$ in oxic environments.

\section{Supplementary material related to this article is available online at: http://www.biogeosciences.net/10/ 3297/2013/bg-10-3297-2013-supplement.pdf.}

Acknowledgements. We acknowledge the support of the captain and crew of R/V Sonne as well as Birgit Quack, chief scientist of the TransBrom-Sonne project. We thank Franziska Wittke for assistance with the measurements of the sulphur compounds. Funding for the Phytooptics group was provided by the HGF Innovative Network Funds (Phytooptics) and via the EU project SHIVA-226224-FP7-ENV-2008-1. Part of this study was performed during a visit of ET at the Phytooptics group supported by the Spanish National Research Council CSIC (project ANERIS PIF08-015) and the Spanish Ministry of Education (Ph.D. European Mentoring Program). We thank Janina Seemann, Erika Allhusen, and Sonja Wiegmann for lab analysis and Anja Bernhardt, Tilman Dinter, Dörte Stange and Kim Quack for their work on board for Phytooptics and all other scientists for their support on board. Financial support for this study was provided by the BMBF SOPRAN grants FKZ 03F0462A and FKZ 03F0611A and by the WGL project TransBrom. The R/V Sonne transit cruise was financed by the BMBF through grant 03G0731A. This work is a contribution to the EU project SHIVA.

The service charges for this open access publication have been covered by a Research Centre of the Helmholtz Association.

Edited by: C. Robinson

\section{References}

Bange, H. W., Bergmann, K., Hansen, H. P., Kock, A., Koppe, R., Malien, F., and Ostrau, C.: Dissolved methane during hypoxic events at the Boknis Eck time series station (Eckernförde Bay, SW Baltic Sea), Biogeosciences, 7, 1279-1284, doi:10.5194/bg7-1279-2010, 2010.

Bates, T. S., Kelly, K. C., Johnson, J. E., and Gammon, R. H.: A reevaluation of the open ocean source of methane to the atmosphere, J. Geophys. Res., 101, 6953-6961, doi:10.1029/95jd03348, 1996. 
Belviso, S., Claustre, H., and Marty, J. C.: Evaluation of the utility of chemotaxonomic pigments as a surrogate for particulate dmsp, Limnol. Oceanogr., 46, 989-995, 2001.

Boden, R., Murrell, J. C., and Schäfer, H.: Dimethylsulfide is an energy source for the heterotrophic marine bacterium sagittula stellata, FEMS Microbiol. Lett., 322, 188-193, doi:10.1111/j.15746968.2011.02349.x, 2011.

Bouillon, R.-C., Lee, P. A., de Mora, S. J., Levasseur, M., and Lovejoy, C.: Vernal distribution of dimethylsulphide, dimethylsulphoniopropionate, and dimethylsulphoxide in the north water in 1998, Deep Sea Res. Pt. II, 49, 5171-5189, doi:10.1016/s09670645(02)00184-4, 2002.

Bürgermeister, S., Zlmmermann, R. L., Georgii, H. W., Bingemer, H. G., Kirst, G. O., Janssen, M., and Ernst, W.: On the biogenic origin of dimethylsulfide: Relation between chlorophyll, atp, organismic dmsp, phytoplankton species, and dms distribution in atlantic surface water and atmosphere, J. Geophys. Res., 95, 20607-20615, doi:10.1029/JD095iD12p20607, 1990.

Cicerone, R. J. and Oremland, R. S.: Biogeochemical aspects of atmospheric methane, Global Biogeochem. Cy., 2, 299-327, doi:10.1029/GB002i004p00299, 1988.

Damm, E., Kiene, R. P., Schwarz, J., Falck, E., and Dieckmann, G.: Methane cycling in arctic shelf water and its relationship with phytoplankton biomass and dmsp, Mar. Chem., 109, 45-59, doi:10.1016/j.marchem.2007.12.003, 2008.

Damm, E., Helmke, E., Thoms, S., Schauer, U., Nöthig, E., Bakker, K., and Kiene, R. P.: Methane production in aerobic oligotrophic surface water in the central Arctic Ocean, Biogeosciences, 7, 1099-1108, doi:10.5194/bg-7-1099-2010, 2010.

David, H. A.: Further applications of range to analysis of variance, Biometrika, 38, 393-409, 1951.

de Angelis, M. A. and Lee, C.: Methane production during zooplankton grazing on marine-phytoplankton, Limnol. Oceanogr., 39, 1298-1308, 1994.

Eberhardt, M. K. and Colina, R.: The reaction of oh radicals with dimethyl sulfoxide, A comparative study of fenton's reagent and the radiolysis of aqueous dimethyl sulfoxide solutions, J. Org. Chem., 53, 1071-1074, 1988.

Ferry, J. G.: How to make a living by exhaling methane, in: Annual review of microbiology, vol. 64, 2010, edited by: Gottesman, S. and Harwood, C. S., Annu. Rev. Microbiol., 453-473, 2010.

Finster, K., Tanimoto, Y., and Bak, F.: Fermentation of methanethiol and dimethylsulfide by a newly isolated methanogenic bacterium, Arch. Microbiol., 157, 425-430, doi:10.1007/bf00249099, 1992.

Fischer, E. and Jones, G.: Atmospheric dimethysulphide production from corals in the great barrier reef and links to solar radiation, climate and coral bleaching, Biogeochemistry, 110, 31-46, doi:10.1007/s10533-012-9719-y, 2012.

Green, D. H., Shenoy, D. M., Hart, M. C., and Hatton, A. D.: Coupling of dimethylsulfide oxidation to biomass production by a marine flavobacterium, Appl. Environ. Microbiol., 77, 31373140, doi:10.1128/aem.02675-10, 2011.

Hatton, A. D.: Influence of photochemistry on the marine biogeochemical cycle of dimethylsulphide in the northern north sea, Deep-Sea Res. Pt. II, 49, 3039-3052, doi:10.1016/s09670645(02)00070-x, 2002.

Hatton, A. D., Malin, G., Turner, S. M., and Liss, P. S.: Dmso: A significant compound in the biogeochemical cycle of dms, Plenum
Press, New York and London, 430 pp., 1996.

Hatton, A. D., Malin, G., and Liss, P. S.: Distribution of biogenic sulphur compounds during and just after the southwest monsoon in the arabian sea, Deep-Sea Res. Pt. II, 46, 617-632, doi:10.1016/s0967-0645(98)00120-9, 1999.

Hatton, A. D., Darroch, L., and Malin, G.: The role of dimethylsulphoxide in the marine biogeochemical cycle of dimethylsulphide, in: Oceanography and marine biology: An annual review, vol. 42, edited by: Gibson, R. N., Atkinson, R. J. A., and Gordon, J. D. M., Oceanography and marine biology, Crc Press-Taylor \& Francis Group, Boca Raton, 29-55, 2005.

Hirata, T., Hardman-Mountford, N. J., Brewin, R. J. W., Aiken, J., Barlow, R., Suzuki, K., Isada, T., Howell, E., Hashioka, T., Noguchi-Aita, M., and Yamanaka, Y.: Synoptic relationships between surface Chlorophyll- $a$ and diagnostic pigments specific to phytoplankton functional types, Biogeosciences, 8, 311-327, doi:10.5194/bg-8-311-2011, 2011.

Iglesias-Rodriguez, M. D., Brown, C. W., Doney, S. C., Kleypas, J., Kolber, D., Kolber, Z., Hayes, P. K., and Falkowski, P. G.: Representing key phytoplankton functional groups in ocean carbon cycle models: Coccolithophorids, Global Biogeochem. Cy., 16, 1100, doi:10.1029/2001gb001454, 2002.

IPCC: Climate change 2007: The physical science basis, Contribution of working group $i$ to the fourth assessment report of the intergovernmental panel on climate change, edited by: Solomon, S., Qin, D., Manning, M., Chen, Z., Marquis, M., Averyt, K. B., Tignor, M., and Miller, H. L., Cambridge University Press, Cambridge, UK and New York, NY, USA, 996 pp., 2007.

Karl, D. M. and Tilbrook, B. D.: Production and transport of methane in oceanic particulate organic matter, Nature, 368, 732 734, 1994.

Karl, D. M., Beversdorf, L., Bjorkman, K. M., Church, M. J., Martinez, A., and DeLong, E. F.: Aerobic production of methane in the sea, Nat. Geosci., 1, 473-478, doi:10.1038/ngeo234, 2008.

Keller, M. D., Bellows, W. K., and Guillard, R. R. L.: Dimethyl sulfide production in marine-phytoplankton, Acs Symposium Series, 393, 167-182, 1989.

Kiene, R. P. and Linn, L. J.: Distribution and turnover of dissolved $\mathrm{dmsp}$ and its relationship with bacterial production and dimethylsulfide in the gulf of mexico, Limnol. Oceanogr., 45, 849-861, 2000.

Kiene, R. P., Oremland, R. S., Catena, A., Miller, L. G., and Capone, D. G.: Metabolism of reduced methylated sulfur-compounds in anaerobic sediments and by a pure culture of an estuarine methanogen, Appl. Environ. Microbiol., 52, 1037-1045, 1986.

Kiene, R. P., Linn, L. J., and Bruton, J. A.: New and important roles for dmsp in marine microbial communities, J. Sea Res., 43, 209224, doi:10.1016/s1385-1101(00)00023-x, 2000.

Krüger, K. and Quack, B.: Introduction to special issue: the TransBrom Sonne expedition in the tropical West Pacific, Atmos. Chem. Phys. Discuss., 12, 1401-1418, doi:10.5194/acpd-121401-2012, 2012.

Lana, A., Bell, T. G., Simó, R., Vallina, S. M., Ballabrera-Poy, J., Kettle, A. J., Dachs, J., Bopp, L., Saltzman, E. S., Stefels, J., Johnson, J. E., and Liss, P. S.: An updated climatology of surface dimethlysulfide concentrations and emission fluxes in the global ocean, Global Biogeochem. Cy., 25, GB1004, doi:10.1029/2010gb003850, 2011. 
Lee, P. A. and De Mora, S. J.: Intracellular dimethylsulfoxide (dmso) in unicellular marine algae: Speculations on its origin and possible biological role, J. Phycol., 35, 8-18, doi:10.1046/j.1529-8817.1999.3510008.x, 1999.

Lee, P. A., de Mora, S. J., and Levasseur, M.: A review of dimethylsulfoxide in aquatic environments, Atmos. Ocean, 37, 439-456, doi:10.1080/07055900.1999.9649635, 1999a.

Lee, P. A., Haase, R., de Mora, S. J., Chanut, J. P., and Gosselin, M.: Dimethylsulfoxide (dmso) and related sulfur compounds in the saguenay fjord, quebec, Can. J. Fish. Aquat. Sci., 56, 16311638, doi:10.1139/f99-094, 1999b.

Longhurst, A.: Ecological geography of the sea, Academic Press, San Diego, 1998.

Merzouk, A., Levasseur, M., Scarratt, M., Michaud, S., Lizotte, M., Rivkin, R. B., and Kiene, R. P.: Bacterial dmsp metabolism during the senescence of the spring diatom bloom in the northwest atlantic, Mar. Ecol.-Prog. Ser., 369, 1-11, doi:10.3354/meps07664, 2008.

Moran, M. A., Gonzalez, J. M., and Kiene, R. P.: Linking a bacterial taxon to sulfur cycling in the sea: Studies of the marine roseobacter group, Geomicrobiol. J., 20, 375-388, doi:10.1080/01490450303901, 2003.

Moran, M. A., Belas, R., Schell, M. A., Gonzalez, J. M., Sun, F., Sun, S., Binder, B. J., Edmonds, J., Ye, W., Orcutt, B., Howard, E. C., Meile, C., Palefsky, W., Goesmann, A., Ren, Q., Paulsen, I., Ulrich, L. E., Thompson, L. S., Saunders, E., and Buchan, A.: Ecological genomics of marine roseobacters, Appl. Environ. Microbiol., 73, 4559-4569, doi:10.1128/aem.02580-06, 2007.

Moran, M. A., Reisch, C. R., Kiene, R. P., and Whitman, W. B.: Genomic insights into bacterial dmsp transformations, in: Annual review of marine science, vol 4, edited by: Carlson, C. A. and Giovannoni, S. J., Annu. Rev. Mar. Sci., 523-542, 2012.

Oremland, R. S., Kiene, R. P., Mathrani, I., Whiticar, M. J., and Boone, D. R.: Description of an estuarine methylotrophic methanogen which grows on dimethyl sulfide, Appl. Environ. Microbiol., 55, 994-1002, 1989.

Owens, N. J. P., Law, C. S., Mantoura, R. F. C., Burkill, P. H., and Llewellyn, C. A.: Methane flux to the atmosphere from the arabian sea, Nature, 354, 293-296, 1991.

Reeburgh, W. S.: Oceanic methane biogeochemistry, Chem. Rev., 107, 486-513, doi:10.1021/cr050362v, 2007.

Rehder, G. and Suess, E.: Methane and $p \mathrm{CO}_{2}$ in the kuroshio and the south china sea during maximum summer surface temperatures, Mar. Chem., 75, 89-108, doi:10.1016/s03044203(01)00026-3, 2001.

Rottgers, R. and Gehnke, S.: Measurement of light absorption by aquatic particles: Improvement of the quantitative filter technique by use of an integrating sphere approach, Appl. Opt., 51, 13361351, 2012.

Schäfer, H., Myronova, N., and Boden, R.: Microbial degradation of dimethylsulphide and related c1-sulphur compounds: Organisms and pathways controlling fluxes of sulphur in the biosphere, $\mathrm{J}$. Exp. Bot., 61, 315-334, doi:10.1093/jxb/erp355, 2010.

Simó, R.: Production of atmospheric sulfur by oceanic plankton: Biogeochemical, ecological and evolutionary links, Trends Ecol. Evol., 16, 287-294, doi:10.1016/s0169-5347(01)02152-8, 2001.

Simó, R.: From cells to globe: Approaching the dynamics of $\mathrm{dms}(p)$ in the ocean at multiple scales, Can. J. Fish. Aquat. Sci., 61, 673684, doi:10.1139/f04-030, 2004.
Simó, R. and Vila-Costa, M.: Ubiquity of algal dimethylsulfoxide in the surface ocean: Geographic and temporal distribution patterns, Mar. Chem., 100, 136-146, doi:10.1016/j.marchem.2005.11.006, 2006a.

Simó, R. and Vila-Costa, M.: Ubiquity of algal dimethylsulfoxide in the surface ocean: Geographic and temporal distribution patterns, Mar. Chem., 100, 136-146, doi:10.1016/j.marchem.2005.11.006, 2006b.

Simó, R., Hatton, A. D., Malin, G., and Liss, P. S.: Particulate dimethyl sulphoxide in seawater: Production by microplankton, Mar. Ecol.-Prog. Ser., 167, 291-296, doi:10.3354/meps167291, 1998.

Simó, R., Pedrós-Alió, C., Malin, G., and Grimalt, J. O.: Biological turnover of dms, dmsp and dmso in contrasting open-sea waters, Mar. Ecol.-Prog. Ser., 203, 1-11, doi:10.3354/meps203001, 2000.

Simó, R., Archer, S. D., Pedros-Alio, C., Gilpin, L., and StelfoxWiddicombe, C. E.: Coupled dynamics of dimethylsulfoniopropionate and dimethylsulfide cycling and the microbial food web in surface waters of the north atlantic, Limnol. Oceanogr., 47, 53-61, 2002.

Spiese, C. E., Kieber, D. J., Nomura, C. T., and Kiene, R. P.: Reduction of dimethylsulfoxide to dimethylsulfide by marine phytoplankton, Limnol. Oceanogr., 54, 560-570, 2009.

Stefels, J.: Physiological aspects of the production and conversion of dmsp in marine algae and higher plants, J. Sea Res., 43, 183197, doi:10.1016/s1385-1101(00)00030-7, 2000.

Stefels, J., Steinke, M., Turner, S., Malin, G., and Belviso, S.: Environmental constraints on the production and removal of the climatically active gas dimethylsulphide (dms) and implications for ecosystem modelling, Biogeochemistry, 83, 245-275, doi:10.1007/s10533-007-9091-5, 2007.

Steinke, M., Malin, G., Archer, S. D., Burkill, P. H., and Liss, P. S.: Dms production in a coccolithophorid bloom: Evidence for the importance of dinoflagellate dmsp lyases, Aquat. Microb. Ecol., 26, 259-270, doi:10.3354/ame026259, 2002.

Sunda, W., Kieber, D. J., Kiene, R. P., and Huntsman, S.: An antioxidant function for $\mathrm{dmsp}$ and $\mathrm{dms}$ in marine algae, Nature, 418, 317-320, doi:10.1038/nature00851, 2002.

Tallant, T. C. and Krzycki, J. A.: Methylthiol:Coenzyme m methyltransferase from methanosarcina barkeri, an enzyme of methanogenesis from dimethylsulfide and methylmercaptopropionate, J. Bacteriol., 179, 6902-6911, 1997.

Taylor, B. B., Torrecilla, E., Bernhardt, A., Taylor, M. H., Peeken, I., Röttgers, R., Piera, J., and Bracher, A.: Bio-optical provinces in the eastern Atlantic Ocean and their biogeographical relevance, Biogeosciences, 8, 3609-3629, doi:10.5194/bg-8-36092011, 2011.

Terao, Y., Mukai, H., Nojiri, Y., Machida, T., Tohjima, Y., Saeki, T., and Maksyutov, S.: Interannual variability and trends in atmospheric methane over the western pacific from 1994 to 2010, J. Geophys. Res.-Atmos., 116, D14120, doi:10.1029/2010jd015467, 2011.

Torrecilla, E., Stramski, D., Reynolds, R. A., Millan-Nunez, E., and Piera, J.: Cluster analysis of hyperspectral optical data for discriminating phytoplankton pigment assemblages in the open ocean, Remote Sens. Environ., 115, 2578-2593, doi:10.1016/j.rse.2011.05.014, 2011. 
Uitz, J., Claustre, H., Morel, A., and Hooker, S. B.: Vertical distribution of phytoplankton communities in open ocean: An assessment based on surface chlorophyll, J. Geophys. Res.-Oceans, 111, C08005, doi:10.1029/2005jc003207, 2006.

van der Maarel, M. J. E. C. and Hansen, T. A.: Dimethylsulfoniopropionate in anoxic intertidal sediments: A precursor of methanogenesis via dimethyl sulfide, methanethiol, and methiolpropionate, Mar. Geol., 137, 5-12, doi:10.1016/s00253227(96)00074-6, 1997.

Vidussi, F., Claustre, H., Manca, B. B., Luchetta, A., and Marty, J. C.: Phytoplankton pigment distribution in relation to upper thermocline circulation in the eastern mediterranean sea during winter, J. Geophys. Res.-Oceans, 106, 19939-19956, doi:10.1029/1999jc000308, 2001.

Vogt, M. and Liss, P. S.: Dimethylsulfide and climate, Surface ocean - lower atmosphere processes, 187, Geophysical Monograph Series, AGU, Washingtion, DC, doi:10.1029/2008GM000790, 2009.
Watanabe, S., Higashitani, N., Tsurushima, N., and Tsunogai, S.: Methane in the western north pacific, J. Oceanogr., 51, 39-60, 1995.

Wiesenburg, D. A. and Guinasso Jr., N. L.: Equilibrium solubilities of methane, carbon monoxide, hydrogen in water and seawater, J. Chem. Eng. Data, 24, 356-360, 1979.

Yang, J. and Yang, G.-P.: Distribution of dissolved and particulate dimethylsulfoxide in the East China Sea in winter, Mar. Chem., 127, 199-209, 2011.

Yoch, D. C.: Dimethylsulfoniopropionate: Its sources, role in the marine food web, and biological degradation to dimethylsulfide, Appl. Environ. Microbiol., 68, 5804-5815, doi:10.1128/aem.68.12.5804-5815.2002, 2002.

Zindler, C., Peeken, I., Marandino, C. A., and Bange, H. W.: Environmental control on the variability of DMS and DMSP in the Mauritanian upwelling region, Biogeosciences, 9, 1041-1051, doi:10.5194/bg-9-1041-2012, 2012. 